Portland State University

PDXScholar

Fall 12-29-2015

\title{
Questions of Citizenship: Oregonian Reactions to Japanese Immigrants' Quest for Naturalization Rights in the United States, 1894-1952
}

Alison Leigh Jessie

Portland State University

Follow this and additional works at: https://pdxscholar.library.pdx.edu/open_access_etds

Part of the Social History Commons, and the United States History Commons Let us know how access to this document benefits you.

Recommended Citation

Jessie, Alison Leigh, "Questions of Citizenship: Oregonian Reactions to Japanese Immigrants' Quest for Naturalization Rights in the United States, 1894-1952" (2015). Dissertations and Theses. Paper 2644. https://doi.org/10.15760/etd.2640

This Thesis is brought to you for free and open access. It has been accepted for inclusion in Dissertations and Theses by an authorized administrator of PDXScholar. Please contact us if we can make this document more accessible: pdxscholar@pdx.edu. 
Questions of Citizenship: Oregonian Reactions to Japanese Immigrants' Quest for Naturalization Rights in the United States, 1894-1952

by

\begin{abstract}
Alison Leigh Jessie
Master of Arts

in

History

Thesis Committee:

Kenneth J. Ruoff, Chair

Katrine Barber

Tim Garrison

Christopher Shortell
\end{abstract}

Portland State University

2015 


\begin{abstract}
This study examines the discrimination against Japanese immigrants in U.S. naturalization law up to 1952 and how it was covered in the Oregonian newspaper, one of the oldest and most widely read newspapers on the West Coast. The anti-Japanese movement was much larger in California, but this paper focuses on the attitudes in Oregon, which at times echoed sentiments in California but at other times conveyed support for Japanese naturalization. Naturalization laws at the turn of the century were vague, leaving the task of defining who was white, and thus eligible for naturalization, to the courts. Japanese applicants were often denied, but until the federal government clarified which immigrants could or could not become citizens, the subject remained open to debate. "Ineligibility to naturalization" was often used as a code for "Japanese" in discriminatory land use laws and similar legislation at the state level in California and in other western states. This study highlights several factors which influenced Oregonian editorials on the subject.
\end{abstract}

First, the fear of offending Japan and provoking war with that empire was a foremost concern of Oregonian editors. California's moves to use naturalization law to prevent Japanese immigrants from owning land were seen as dangerous because they damaged relations with Japan and could lead to war. The Oregonian went so far as to recommend Japanese naturalization during the First World War. However, war and foreign relations were federal issues, thus the second theme seen throughout Oregonian editorials was deference to federal authority on 
questions related to naturalization. While suggesting that naturalization for existing immigrants might be good policy, the Oregonian urged the federal government to settle the matter. Once the Supreme Court ruled against Asian naturalization in 1922 and 1923, the Oregonian dropped its push for such rights. Nativism was another theme that influenced opinions at this time, and before 1923 the Oregonian generally opposed extreme nativist positions, while at the same time advocating for limits to Japanese immigration and against mixed marriages.

This paper does not deal with the incarceration of Japanese Americans during World War II because naturalization was not the issue for the antiexclusion movement at the time. Citizenship did not give the Nisei, second generation Japanese American citizens, any protection against their wartime removal from the West Coast.

This study returns to the issue of naturalization for Japanese immigrants after the war, as a number of Issei, first generation Japanese immigrants, still lived in the United States but were denied citizenship, even though most had been in the country for decades at that point. There was less opposition to Japanese naturalization after the war due to the noted loyalty of the Japanese during the war, the focus on human rights as an issue promoted by the new United Nations, and Cold War politics which demanded better relations with Japan and thus fairer treatment of Japanese living in the United States. The Oregonian editorials reflected the shift in public opinion throughout the country in favor of lifting the 
racial bar to citizenship. Japanese Americans in Oregon were active in the campaign to change U.S. naturalization law. The issue was more important to the Japanese American community than it was to the Oregonian editorial board by then, as other Cold War events took precedence on the front and op-ed pages of the newspaper. 


\section{Acknowledgments}

Firstly, I would like to thank my adviser, Kenneth Ruoff, for helping me contextualize my research. I learned a great deal in his classes about Japan in the

early twentieth century and this understanding of the Japanese empire in the world informed my interpretation of the domestic debate regarding naturalization. I am grateful for the connections with other scholars on Japanese Americans he arranged for me while I was in the graduate program.

I am also grateful for the support of my thesis committee. Tim Garrison helped put me in the right direction, suggesting that I use local resources and take an Oregon approach to my topic. Christopher Shortell's constitutional law and Supreme Court courses were useful for interpreting federal laws and the courts in my research. I especially appreciated the guidance I received from Katrine Barber in her seminar class, where I learned how to write history. Her feedback on my thesis draft was invaluable.

Finally, I thank the James Madison Memorial Foundation for giving me the opportunity to study history at the graduate level so I could improve my teaching in the high school classroom. Being a graduate student of history and doing the research and writing of this paper has helped me teach students what historians really do. The graduate program in history at Portland State University, combined with the Madison Fellowship summer seminar at Georgetown 
University, and the connections I made with other Madison Fellows, have all shaped me as a historian and a teacher. 


\section{Table of Contents}

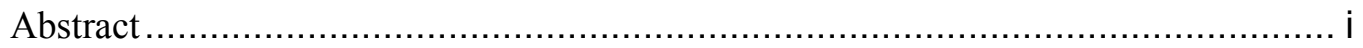

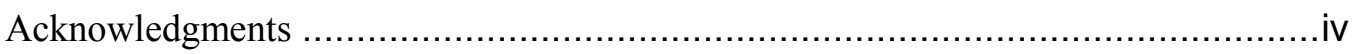

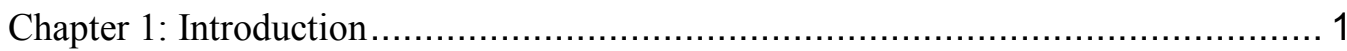

Chapter 2: From Early Japanese Immigration to the Passage of the California Alien Land

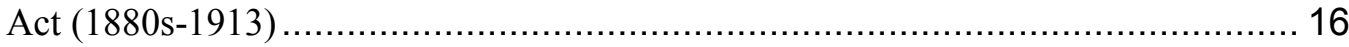

Chapter 3: Oregonian Support for Naturalization and Appeals to Federalism (1913-1924)

Chapter 4: The Postwar Movement to Change Racial Requirements for Naturalization

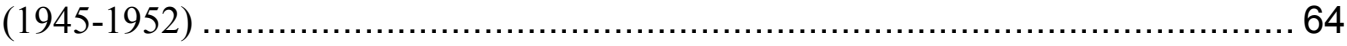

Chapter 5: Effects of the McCarran-Walter Act in Oregon (1952) ..................... 87

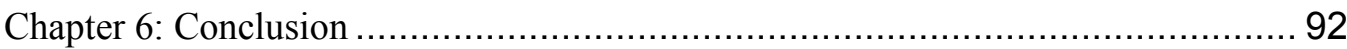

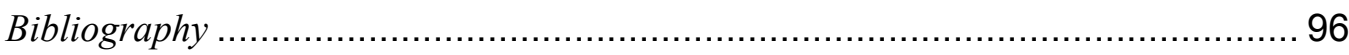

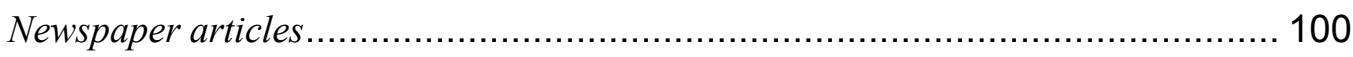




\section{Chapter 1: Introduction}

Homer Yasui, a Nisei living in Portland, Oregon, recalled in 2012 that when finally given the opportunity to do so, his parents and his wife's widowed mother "jumped at the chance to become Americans." He described his motherin-law's 1953 naturalization examination like this:

Examiner: "Who was the first President of the United States?"

Mitsuye: "Jo-jee Wa-shingu-tohn."

Examiner: "Good. You pass."

Mitsuye: "Zotsu oh-ru?" (That's all?) ${ }^{1}$

According to Yasui, she had worked so hard, attending weeks of naturalization classes and studying on her own, that she felt disappointed with how easy the test was. Ironically, after struggling against nearly sixty years of being ruled "ineligible for citizenship," Japanese immigrants encountered little difficulty when their time finally came.

\section{Background}

When the First Congress passed the 1790 Naturalization Act, they intended to withhold the privilege of American citizenship from African slaves and Native Americans, and thus admitted as naturalized citizens any "free white person" who had lived in the United States for two years. ${ }^{2}$ A century later, federal courts would debate the application of such language to the new wave of

\footnotetext{
${ }^{1}$ Personal email from Homer Yasui, February 22, 2012.

2 Ronald Takaki, A Different Mirror: A History of Multicultural America (Boston: Back Bay Books, 1993), 79-80.
} 
Japanese immigrants. The outcome of these naturalization cases would have huge consequences for Japanese immigrants and their children, as well as for diplomatic relations between Japan and the United States. National foreign politics often clashed with state and local sentiments; at different times one overpowered the other. In the first quarter of the 20th century, anti-Japanese attitudes ultimately trumped more cooperative viewpoints, setting the stage for tensions between Japan and the U.S. that would culminate in the Pacific War. After the war, however, opinion shifted and in 1952 the racial requirement for citizenship was lifted.

\section{Purpose}

This paper will illuminate the significance of the naturalization issue in the larger debate over Japanese immigration to the United States, review the court cases when Japanese immigrants challenged U.S. naturalization laws, and analyze reactions in Oregon in their national and international contexts. It will argue that the category "ineligible to citizenship" was used to justify discriminatory state and federal laws and demonstrate that both supporters and opponents of Japanese exclusion were aware that such discrimination could lead to war between the U.S. and Japan. While there were some in Oregon advocating more friendly relations with the Japanese and trying to distinguish Oregon's approach to Japanese immigrants from that of its western neighbors, during the height of national nativist fervor most Oregonians favored excluding Japanese and other Asians from obtaining citizenship or living in the United States, and Oregon in 1923 
followed California's lead by passing an alien land law that withheld property rights from "aliens ineligible to citizenship."

The issue of naturalization for Japanese immigrants in the U.S. was largely dropped from the mainstream press once the Supreme Court ruled against it in 1922 and federal lawmakers used the decision to block future Asian immigration from 1924. Many of the arguments from white Oregonians previously in favor of Japanese naturalization had relied on a federalist perspective which held that the states should defer to federal authority on the question. During the Pacific War, U.S. citizenship did not afford expected rights to many Japanese American citizens, and there was not a vocal movement for naturalization rights while the U.S. and Japan were at war.

After World War II, the Japanese were the biggest immigrant group still excluded from naturalized citizenship. This paper will also examine how and why Oregonians contributed to the passage of the 1952 McCarran-Walter Immigration and Naturalization Act and what immediate impact the legislation had on Oregon. It will make three main arguments about the postwar debate regarding Japanese naturalization: that after the war, the racial barrier to citizenship continued to create hardships for Japanese aliens but there was a shift in public sentiment and efforts to overturn discriminatory laws gained momentum; that the movement to end the racial barrier to citizenship had widespread support and was justified by the demonstrated loyalty of Japanese American soldiers, the need to improve foreign relations in the new Cold War, and basic appeals to human rights; and 
that, for most Japanese Americans, ending the racial barrier to citizenship was important enough that it was worth supporting the McCarran-Walter bill, even though it continued to discriminate in immigration, although there was an often overlooked minority that voiced opposition to the compromised legislation.

The McCarran-Walter Act was contentious because while it opened naturalization to all immigrants regardless of race or ethnicity, it reaffirmed national origins quotas that continued a pattern of discrimination against Asians and others. For the majority of the Japanese American community in Oregon and elsewhere, the national origins quotas were a price worth paying to secure Issei citizenship. Supporters of dropping racial requirements for naturalization, which at the time would affect more Japanese residents than any other group, cited the loyalty of Japanese American veterans, the importance of improving international relations, and the inherent human rights at stake. At the same time, those favoring upholding national origins quotas expressed fear of increased Asian immigration and saw the quotas as the best way to maintain the status quo. The Act was a compromise between these two contradictory positions. In Oregon, most documentary evidence shows widespread support for the new naturalization policy despite its limits, and Oregonian Issei, like long-time Japanese residents up and down the Pacific Slope, took advantage of the opportunity to become naturalized U.S. citizens from 1953 onwards.

\section{Historiography}

Much has been written about the history of U.S. immigration and 
naturalization policy. Historians have documented the immigrant experience throughout American history, as well as the changing landscape of U.S. policy affecting immigrants. Some of the historians who informed this paper by were Roger Daniels, Ronald Takaki, and Paul Spickard. Well-known for their scholarship on immigration to the United States in general, these three scholars have also focused much of their research on the Japanese experience in America.

University of Cincinnati Professor Emeritus Roger Daniels is one of the most prolific writers on American immigration history in general and Japanese American history specifically. Daniels has written an overview of U.S. immigration history, documenting different waves of immigration, as well as a book focusing on the history of immigration policy in U.S. law since the passage of the Chinese Exclusion Act. ${ }^{3}$ Similarly, Ronald Takaki's A Different Mirror is a survey of U.S. history through the immigrant lens, arguing that many different immigrant groups shaped the American story.

University of California at Santa Barbara Professor Paul Spickard integrated immigration history and ethnic studies in his 2007 book, Almost All Aliens. His work encourages scholars to go beyond the traditional lens of immigrant as assimilant and look at the immigrant experience in the context of international relations and domestic race relations. He examined different immigrant groups within three paradigms: the "Ellis Island" assimilation model, a

\footnotetext{
${ }^{3}$ Roger Daniels, Coming To America: A History of Immigration and Ethnicity in American Life (Princeton, NJ: Visual Education Corporation, 2002); and Roger Daniels, Guarding the Golden Door: American Immigration Policy and Immigrants Since 1882 (New York: Hill and Wang, 2004).
} 
transnational diasporic model, and a panethnic formation model, arguing that the second two are more useful. These approaches provided context for the present study.

Several scholars have recently focused academic attention on the construction of race as a key factor in immigration policy. Since 1996, Ian F. Haney Lopez, Matthew Frye Jacobson, and David R. Roediger have written about whiteness and those excluded from the definition of whiteness. Roger Daniels also focused on race in his book Not Like Us, comparing the experiences of immigrants with those of Native Americans and African Americans.

Other historians have illuminated the importance of immigration in the history of the American West. Elliott Robert Barkan's From All Points: America's Immigrant West, 1870s-1952 examines the multitude of immigrants that populated the West, including several useful chapters regarding the Japanese that contributed greatly to my research. Barkan argues the history of immigrants in the West has been downplayed, thus his effort to bring them to "center stage." The Chinese and Japanese are the major immigrant groups on the West Coast in the early 20th century, and both suffered discrimination at the hands of white westerners. Barkan describes the exclusionist hysteria that met their growing numbers and success but also recognizes the agency of the people themselves. He discusses the nationalities of the petitioners who challenged naturalization law in the courts and addresses the debate over the meaning of "whiteness." Similarly, historian Gail Nomura insists upon the centrality of the Asian immigrant story to 
the larger study of the American West, linking the development of the West with events in Asia. ${ }^{4}$

Several works deal specifically with the Asian American immigrant experience. Daniels and Takaki have contributed to this field, as well as Sucheng Chan, who presents an overview of Asian American history in Asian Americans, including a chapter on resistance to discrimination in immigration and naturalization law as well as in economic opportunities; Gary Okihiro, who argues that the Asian American experience has not fit into the binary American historical narrative of whites and blacks; and Angelo Ancheta, whose Race, Rights, and the Asian American Experience explores the laws and court cases that have impacted Asian immigrants and Asian Americans. ${ }^{5}$ Ancheta argues that anti-Asian racism differed from anti-black racism because the movement against Asians has been about excluding them from the mainstream, while discrimination against African Americans has been about white superiority.

The work of several historians focusing more narrowly on Japanese immigrants greatly informed this study, especially those that examined legal issues. Frank Chuman's The Bamboo People provided an overview of Japanese American legal history from the 1860s through the 1950s. Chuman's study partly informed Robert Wilson and Bill Hosokawa's East to America: A History of the Japanese in the United States, which underscores the importance of the laws and

\footnotetext{
${ }^{4}$ Gail M. Nomura, "Significant Lives: Asia and Asian Americans in the History of the U.S. West." Western Historical Quarterly, 25: 1994.

${ }^{5}$ Roger Daniels, Asian America; Ron Takaki, Strangers From A Different Shore; Sucheng Chan, Asian Americans: An Interpretive History (New York: Twayne Publishers, 1991); Gary Y. Okihiro, Common Ground: Reimagining American History; Angelo N. Ancheta, Race, Rights, and the Asian American Experience (New Brunswick, New Jersey: Rutgers University Press, 2001).
} 
court cases to the Asian immigrant experience. ${ }^{6}$ Yuji Ichioka set the bar for Japanese American historians with his study of first-generation Japanese immigrants. His book, The Issei, examines this group until 1924, including the importance of the naturalization issue. Ichioka wrote an essay on the Ozawa case, while Gabriel Chin examined the case of Yamashita. ${ }^{7}$ Eiichiro Azuma's Between Two Empires, as well as several other articles, continues Ichioka's work but especially illuminates the transnational experience of both the Issei and the next generation, the Nisei. Without access to full American citizenship, Azuma argues that the Issei transferred their goals to their American-born children, and that both generations lived caught between the country they had rejected and the one that rejected them.

Roger Daniels has also written extensively on Japanese immigrants. Most useful for this study was The Politics of Prejudice, his 1962 work on the Japanese exclusion movement in California. In the book, Daniels argued that the Japanese faced more sustained opposition than any other voluntary immigrant group, and that such racism can be explained by the tradition of anti-Asian prejudice that already existed in California (remnants of the Chinese exclusion movement), the competition resulting from Japanese success in America, and American suspicion that accompanied the rise of the Japanese empire. This definitive study provided a point of comparison for my research on Oregon, as newspaper editorials in

\footnotetext{
${ }^{6}$ Robert A. Wilson and Bill Hosokawa, East To America: A History of the Japanese in the United States (New York: William Morrow and Company, 1980).

${ }^{7}$ Gabriel J. Chin, "Twenty Years on Trial: Takuji Yamashita's Struggle for Citizenship," in Race on Trial: Law and Justice in American History, ed. Annette Gordon Reed (New York: Oxford University Press, 2002).
} 
Oregon at times echoed but at other times rejected themes in California.

Other scholars who have focused on Oregon also informed this paper. The oldest published history of the Japanese in Oregon came from Marjorie Stearns in 1938. ${ }^{8}$ Her work, and what followed in 1966 by Marvin Pursinger, chronicle the settlement of the Issei, relying mostly on census statistics and a 1920 report commissioned by then Governor Ben Olcott. Barbara Yasui published her study of Japanese immigrants in Oregon in 1975, drawing on some of the same data but also highlighting the struggles against discrimination. ${ }^{9}$ Professor Azuma summarized Japanese history in Oregon in 1993, adding rich details of the cultural associations that sustained the community and participated in legal struggles. ${ }^{10}$ Azuma drew on more Japanese language resources than previous studies. Daniel Johnson established that the small population in Oregon meant that the exclusion movement never gained as much strength as in California, but that Japanese immigrants still faced opposition, especially in the economic sphere. ${ }^{11}$ Johnson's work focuses on Oregon's 1923 Alien Land Law but does not go deeper into public opinion on the issue of naturalization. Useful for providing context into the experience of Japanese in Portland was William Toll's article about Japanese families in $1920 .^{12}$ Portland State University graduate student

\footnotetext{
${ }^{8}$ Marjorie Stearns, "The Settlement of the Japanese in Oregon," Oregon Historical Quarterly, 39:3 (Sept 1938), 262-269.

${ }^{9}$ Barbara Yasui, “The Nikkei in Oregon, 1834-1940," Oregon Historical Quarterly, 76:3 (September 1975), 225-257.

${ }^{10}$ Eiichiro Azuma, “A History of Oregon's Issei, 1880-1952”, Oregon Historical Quarterly, 94: 1993/1994.

${ }^{11}$ Daniel Johnson, “Anti-Japanese Legislation in Oregon, 1917-1923,” Oregon Historical Quarterly, 97: 1996.

${ }^{12}$ William Toll, "Permanent Settlement: Japanese Families in Portland in 1920," The Western
} 
Robert Hegwood's 2010 Master's thesis describes a shift towards civic nationalism in the postwar period that included white support for the Japanese American Citizen's League's efforts to overturn the Oregon Alien Land Law. Much of the body of the thesis focuses on the Portland JACL from 1946 and 1947. His work utilized the recently archived Portland JACL papers and discusses the campaign to change naturalization law, but does not follow the issue to its 1952 resolution, nor does he uncover any opposition to the immigration legislation in Portland. ${ }^{13}$ Finally, Peggy Nagae's recent work on Asian women immigrants focuses on Oregon and naturalization. ${ }^{14}$ This thesis is informed by this research but delves deeper into the debate over citizenship as it played out in the pages of the Oregonian newspaper.

On the subject of the 1952 McCarran-Walter Act, Roger Daniels again proved a useful source with his Immigration and the Legacy of Harry S. Truman, which includes a chapter titled, "The Cold War and Immigration," addressing the "paradox" of the McCarran-Walter Act's lifting of the racial ban on naturalization while simultaneously placing racial restrictions on immigration. ${ }^{15}$ The chapter also discusses the substitute Lehman-Humphrey bill and Truman's veto, but does not identify any Japanese American opposition to the immigration quotas. Japanese American opposition to the McCarran-Walter Act is the least explored

Historical Quarterly, 28:1 (Spring, 1997), 18-43.

${ }^{13}$ Robert Hegwood, "Erasing the Space Between Japanese and American: Progressivism, Nationalism, and Japanese American Resettlement in Portland, Oregon, 1945-1948" (Portland State University: Master's Thesis, 2010).

${ }^{14}$ Peggy Nagae, "Asian Women: Immigration and Citizenship in Oregon," Oregon Historical Quarterly, 113 (2012): 334-359.

${ }^{15}$ Roger Daniels, Immigration and the Legacy of Harry S. Truman (Kirksville, Missouri: Truman State University Press, 2010). 
topic in the literature reviewed above. In 2008 Greg Robinson of the University of Quebec, Montreal, wrote about liberal Japanese Americans forming an alliance with black civil rights activist and Communist party supporter Paul Robeson. ${ }^{16}$ He continued to explore this connection in his 2012 book, After Camp: Portraits in Midcentury Japanese American Life and Politics, introducing two Japanese Americans who spoke out against McCarran-Walter, S.I. Hayakawa (later California's first Japanese American senator) and journalist Togo Tanaka.

Historians such as Izumi Hirobe and Walter LaFeber bring an international perspective to the issue of U.S. naturalization laws and Japanese immigrants. Hirobe examined in great depth the 1924 "Japanese Exclusion" Act from both the American and Japanese sides of the Pacific. ${ }^{17}$ Walter LaFeber's 1997 work, The Clash, examines U.S.-Japanese relations from Commodore Matthew Perry’s 1852 expedition to Japan to the (then) present, providing great context for understanding the significance of U.S. immigration and naturalization policy in the early 20th century, although he only briefly discusses the 1924 Immigration Act and does not mention the court cases or the McCarran-Walter Act. ${ }^{18}$ The most useful work for placing U.S. naturalization law in an international context is Marilyn Lake and Henry Reynolds' Drawing the Global Colour Line. ${ }^{19}$ The

\footnotetext{
${ }^{16}$ Greg Robinson, "Paul Robeson and Japanese Americans," Nichi Bei Times (San Francisco), March 13, 2008.

${ }^{17}$ Izumi Hirobe, Japanese Pride, American Prejudice: Modifying the Exclusion Clause of the 1924 Immigration Act (California: Stanford University Press, 2001).

${ }^{18}$ Walter LaFeber, The Clash: U.S.-Japanese Relations Throughout History (New York: W.W. Norton \& Co., 1997).

${ }^{19}$ Marilyn Lake and Henry Reynolds, Drawing the Global Colour Line: White Men's Countries and the International Challenge of Racial Equality (Cambridge: Cambridge University Press, 2008).
} 
exclusion of Japanese and other Asian immigrants from the privileges of immigration and naturalization was not unique to the United States, but was a wider movement to maintain a hegemony of "white men's countries" including Canada, Australia, New Zealand, and South Africa.

The present study contributes to the existing scholarship by focusing on the issue of naturalization as a key factor in the immigration debate. It differs from previous studies in that it tells the story of naturalization rights for Japanese immigrants from beginning to end (the 1894 Saito case to the 1952 McCarranWalter Act) and that it focuses on opinions in Oregon, especially those espoused by the editorial board of Oregon's largest newspaper, the Oregonian. The editorin-chief at the turn of the century, Harvey W. Scott, was known nation-wide as one of the strongest editors in the country, and had reputation for "effective journalism in the guidance of public opinion.. ${ }^{20}$ Scott was a conservative Republican, but allowed diverse viewpoints to be expressed in his newspaper. ${ }^{21}$ An obituary for Scott in San Francisco said he had made the Oregonian "a paper whose influence has been almost dictatorial in a larger area than any other paper in the country." ${ }^{22}$ Following Scott's death in 1910, the Oregonian continued to have wide readership and was described in 1928 such that "their influence continues to run through the fabric of community life and to mould public

\footnotetext{
${ }^{20}$ Leslie M. Scott, “"The Oregonian' in Oregon History,” Oregon Historical Quarterly 29:3 (September 1928), 232.

${ }^{21}$ Jason Stone, "Portland Morning Oregonian," Historic Oregon Newspapers website, University of Oregon Libraries, http://oregonnews. uoregon.edu/history/oregonian/. Accessed Oct. 30, 2015.

22 "Harvey W. Scott, Editor, Is Dead." San Francisco Call, August 8, 1910, 3.
} 
opinion."23 A new editor came in 1935 and reportedly brought the prestige of the paper to the level it had enjoyed under Scott's editorship until the 1940s. ${ }^{24}$ As the state's largest paper, the editorials in the Oregonian throughout the period of this investigation were widely read and influential, and therefore provide evidence of mainstream public opinion on the subject of Japanese immigration and naturalization. While the Japanese population in Oregon was much smaller than other western states, many of the same issues concerning immigration and naturalization that caused controversy in California and elsewhere on the Pacific Slope were present in Oregon. However, there were also attempts to support Japanese immigrants by white Oregonians in order to distinguish the state from its neighbors.

\section{Chapter Summaries}

Chapter Two focuses on the early period of Japanese immigration and the question of naturalization, beginning with a review of the anti-Chinese movement of the 1870 s that preceded the onstart of Japanese immigration to the United States. Early court cases regarding naturalization are addressed, as well as the increasing significance of the question of U.S. citizenship as it related to the rising anti-Japanese movement. California laws affecting Japanese immigrants as reported and commented on in the Oregonian are analyzed, beginning with a 1906 school segregation incident in San Francisco and culminating in the 1913 California Alien Land Law. Opinions expressed in the Oregonian on the subject

${ }^{23}$ Scott, "The Oregonian Newspaper in Oregon History," 234.

${ }^{24}$ Harry H. Stein, "The Oregonian Navigates the Great Depression," Oregon Historical Quarterly 114:2 (2013), 179. 
of Japanese immigrants during this period focused largely on the perceived threats of intermarriage and continued immigration. At the same time, much confusion existed regarding naturalization law and race.

The California Alien Land Act of 1913 was the first state law to restrict the rights of Japanese immigrants without specifically identifying them but by using the term "aliens ineligible to citizenship." This phrase was used to deny equal rights to the Issei while trying not to offend the government of Imperial Japan. Chapter Three focuses on the decade following the California law when the anti-Japanese movement was its height in the state. Especially strong in California, the exclusionist movement attracted members up and down the West Coast; however, a new counter movement pushed for Japanese naturalization rights, gaining some support amongst white Oregonians. This chapter examines Oregonian newspaper coverage of the pro-Japanese naturalization movement, especially editorial responses to national figures like Sidney Gulick and K.K. Kawakami. The chapter ends with the 1922 Ozawa case and 1924 Immigration Act.

The treatment of Japanese immigrants and Japanese Americans living on the West Coast at the advent of World War II is well known and is not the subject of this paper. Citizenship did not prevent the forced removal of native-born Japanese Americans and the subsequent incarceration of Japanese families might have discouraged the Issei from desiring naturalization; however, rather than give up the dream of American citizenship, Japanese immigrants and their children 
renewed their fight for naturalization rights after the war. Chapter Four examines the post-war period, when anti-alien laws excluding those "ineligible for citizenship" were finally overturned in court and Japanese Americans in Oregon and elsewhere lobbied for a new naturalization bill, resulting in the McCarranWalter Act of 1952. I analyze archival material from the Portland Japanese American Citizen's League and compare the activism of the Portland Japanese community and their supporters with national action for and against the new law.

Chapter Five briefly looks at the impact of the McCarran-Walter Act on Oregon Issei, as well as the JACL's national campaign to improve the compromises made in the 1952 law. Asian immigrants were still subject to discriminatory quotas until the new immigration law of 1965.

The conclusion summarizes the main themes that influenced the Oregonian's stance on Japanese naturalization: concerns about foreign relations with Japan, deference to federal authority, reactions to nativism, and questions about the legal definition of whiteness. By 1952, most Oregonians and Americans were in favor of naturalization for Japanese immigrants, so the Oregonian did not need to make a strong case. Cold War concerns influenced the need for changes to naturalization law, but also took priority over the issue of Japanese naturalization on the front and op-ed pages of the Oregonian newspaper. 


\section{Chapter 2: From Early Japanese Immigration to the Passage of the \\ California Alien Land Act (1880s-1913)}

Asian immigration angered nativists on the West Coast, especially in the state of California. The exclusion movement had success restricting Chinese immigration and naturalization, and renewed efforts when the Japanese became the bigger perceived threat. As efforts to discriminate against Japanese immigrants were made in California, the Oregonian cautioned that such efforts would harm foreign relations with Japan, and as foreign relations was were best left to federal authorities, Oregonian editorials criticized California's rogue actions. Concerns over federalism and the possibility of war with Japan were the dominant themes in these editorials. While not going so far as to advocate for Japanese citizenship, in the period leading up to the passage of California's 1913 Alien Land Act, the Oregonian deferred to the federal government on the question of naturalization.

\section{Anti-Chinese Statutes Set the Stage}

The Chinese were the first Asian immigrants to face widespread hostility in the western United States. They came for the California Gold Rush, and stayed to work building the transcontinental railroad and later as migrant farm workers or urban laborers. ${ }^{25}$ After the Civil War, Congress passed the 14th Amendment, which stated that any person born in the United States was an American citizen.

\footnotetext{
${ }^{25}$ Sucheng Chan, Asian Americans: An Interpretative History (New York: Twayne Publishers, 1991), 28-33.
} 
Congress also passed a new naturalization law in 1870 including "aliens of

African nativity and persons of African descent," but resisted attempts by Radical Republican Senator Charles Sumner to include people of all races. ${ }^{26}$ The restriction was meant to prevent Chinese and Native Americans from gaining citizenship, and the Supreme Court upheld the ban in 1878 (In re Ah Yup). ${ }^{27}$ Californians attempted to exclude Chinese immigrants with a state statute prohibiting their entry, but in 1875 the U.S. Supreme Court ruled in Chy Lung v. Freeman that only Congress could decide who could enter the country. ${ }^{28}$ Congress did just that with the 1882 Chinese Exclusion Act, including a specific ban on Chinese naturalization. ${ }^{29}$ (American-born Chinese, however, were still afforded citizenship by the 14th Amendment, the Supreme Court ruled in 1898, U.S. v. Wong Kim Ark. ${ }^{30}$ Native Americans, however, were not guaranteed birthright citizenship, the Supreme Court ruled in Elkv. Wilkins in 1884.) With Chinese immigration cut off, Japanese immigrants, recently released from Tokugawa-era travel bans, began to fill labor demands in western states. ${ }^{31}$

\footnotetext{
${ }^{26}$ Roger Daniels, "United States Policy Towards Asian Immigrants: Contemporary Developments in Historical Perspective," International Journal 48 (1993), 314.

${ }^{27}$ Ancheta, Race, Rights, and the Asian American Experience, 23.

${ }^{28}$ Frank F. Chuman, The Bamboo People: The Law and Japanese Americans (Del Mar, California: Publisher's Inc., 1976), 8.

${ }^{29}$ New scholarship points out that the original 1882 Act did not completely exclude Chinese immigrants, nor did it intend to, as many lawmakers worried about treaty obligations with China. A new law in 1888 ended previous loopholes that allowed Chinese residents the right to return to the United States and gave the law stronger enforcement provisions. Beth Lew-Williams, "Before Restriction Became Exclusion: America's Experiment in Diplomatic Immigration Control," Pacific Historical Review 83 (February 2014), 24-56.

${ }^{30}$ Ancheta, Race, Rights, and the Asian American Experience, 23.

${ }^{31}$ Eiichiro Azuma, “A History of Oregon's Issei, 1880-1952,” Oregon Historical Quarterly 94 (1993/1994), 316.
} 


\section{The Question of Japanese Naturalization}

When the first case of a Japanese immigrant petitioning for citizenship occurred in 1894, the Oregonian noted the ruling in a short piece on the second page. A U.S. District Court in Massachusetts ruled that Shebaito Saito was prohibited from naturalizing because "like the Chinese, the Japanese do not come within the term 'white persons." "32 However, four years after In re Saito, Japan was an emerging world power, having defeated China in the Sino-Japanese War and establishing "most favored nation" status in treaty negotiations with the United States, so U.S. State Department officials expressed the belief that Japanese immigrants would qualify for naturalization. ${ }^{33}$ The question that would arise in later court cases was this: did U.S. naturalization law, by not naming people of Japanese ancestry, intend to include by not specifically excluding, or vice versa? Over the next twenty-five years, the Oregonian continued to explore this question.

An early naturalization case that was covered in the Oregonian was the status of a law student in Washington State who passed the bar examination in 1902. ${ }^{34}$ Takuji Yamashita filed his citizenship petition, however, his admittance to the bar was blocked by the Washington Supreme Court. ${ }^{35}$ Yamashita argued his own case, pointing out that Washington admitted other lawyers to the bar who

32 “Japanese Not White Persons," Oregonian, June 28, 1894, 4.

33 “'Our Japanese Citizens," Oregonian, February 6, 1898, 4.

34 "May Japanese Practice Law?" Oregonian, May 17, 1902, 4.

${ }^{35}$ Gabriel J. Chin, "Twenty Years on Trial: Takuji Yamashita's Struggle for Citizenship," in Race on Trial: Law and Justice in American History, ed. Annette Gordon Reed (New York: Oxford University Press, 2002), 104. 
came from states that did not have citizenship requirements, that the framers of the 1790 Naturalization Act did not intend to prohibit Japanese naturalization, as there were no Japanese in America at that time, and that the addition of "aliens of African nativity" could permit Asians born in Africa and thus could not mean to exclude Asians as a race. The state argued that Japanese were of the same race as the excluded Chinese and denied Yamashita's petition for admittance to the bar on the grounds that his citizenship was not legal.

In 1904 the Oregonian published a lengthy letter by Portland real estate developer W.M. Killingsworth criticizing U.S. immigration and naturalization policy. ${ }^{36} \mathrm{He}$ did not specifically mention any one nationality, but expressed general concern over the prospect of new immigrants obtaining the right to vote. This viewpoint was widely held by many white Protestants across the country at this time, who put pressure on politicians to act. The Basic Naturalization Act of June 29, 1906, codified all previous existing laws, continuing the somewhat vague definition of whiteness and leaving exclusionists wanting more. ${ }^{37}$

\section{Diplomatic concerns create tensions}

In October 1906, the San Francisco Board of Education closed white public schools to Japanese children, as they already segregated Chinese students, regardless of their citizenship status. ${ }^{38}$ Realization of this racially-based discrimination deeply offended many in Japan, who were proud of their recent

\footnotetext{
36 "No Open Door: Immigration and Naturalization Laws Too Lax for Good," Oregonian, January 22, 1904, 5.

${ }^{37}$ Elliott Robert Barkan, From All Points: America's Immigrant West, 1870s-1952, (Indiana: Indiana University Press, 2007), 135.

${ }^{38}$ Chuman, The Bamboo People, 19-20.
} 
victory over Russia. The Russo-Japanese War created fears of a "Yellow Peril" in the United States, but President Theodore Roosevelt understood the sensitivity of the situation in San Francisco and sent the Secretary of Commerce and Labor to investigate. ${ }^{39}$ In a speech to Congress on December 4, Roosevelt warned that hostility toward the Japanese in California "may be fraught with the gravest consequences to the nation." ${ }^{40}$ The president's suggestion that Japanese immigrants ought to be naturalized raised cries of protest from the California press. The Sacramento Union declared, "Not even the big stick is big enough to compel the people of California to do a thing which they have a fixed determination not to do." ${ }^{41}$ In Portland, an Oregonian editorial chided the San Francisco school board, warning that the city "may feel the force of the federal arm should her recalcitrancy against our treaty obligations continue. ${ }^{, 22}$ The editorial called Roosevelt's message regarding the "moral obligations of the nation... illuminating and prophetic." This deference to the federal government against the rogue actions of California characterizes many of the opinions given by the Oregonian board throughout California's anti-Japanese exclusionist push. This does not mean, however, that the Oregonian endorsed Japanese naturalization rights at this time, but that it took the federal line over states' rights when it came to immigration and naturalization.

Oregonian coverage of the San Francisco school segregation issue

\footnotetext{
39 Ibid., 24.

${ }^{40}$ Ibid., 27.

41 “California Is In Rebellious Mood: Resents Roosevelt's Words on Japan,” Oregonian, December 6, 1906, 1.

42 “The President's Message," Oregonian, December 5, 1906, 6.
} 
included many different viewpoints siding with and against the president. West Coast congressmen generally opposed Roosevelt's proposal to naturalize Japanese immigrants, with the exception of Representative Francis Cushman from Washington, who suggested that "yellow men might make as good citizens as white men. ${ }^{43}$ On this point the Oregonian editorial board opined that Cushman was "in accord with the President but very much out of harmony with the rest of the Washington delegation as well as the sentiment of most of his constituents. Washington, perhaps more than any other Pacific coast state except California, is in a position to understand fully what unlimited Japanese immigration encouraged by naturalization rights would mean. ${ }^{\circ 4}$ While the Oregonian did not want California to go against the President and risk offending Japan, the board also did not agree with the President's idea to extend naturalization rights.

Outside of the West Coast, Representative John Jenkins of Wisconsin, Chairman of the House Judiciary Committee, questioned whether the segregation order violated the 1895 U.S.-Japan treaty but said it was "cruel and un-American" to raise the specter of war. ${ }^{45}$ This allusion to war demonstrates the gravity of the school board's action. The Oregonian also reported that University of California, Berkeley, President Benjamin Wheeler had noted the importance of maintaining good relations with Japan, saying, "Japan is a first-rate power and whatever is

43 "Cushman Favors Japanese: Believes Color Does Not Make Good Americans," Oregonian, December 6, 1906, 4.

${ }^{44}$ Untitled editorial, Oregonian, December 7, 1906, 10.

45 "Depends on Treaty's Terms: Jenkins Says If They Don't Cover Schools, Japan Can't

Complain," Oregonian, December 6, 1906, 4. 
done will have to be done with her consent and cooperation."46

The school segregation issue was tied to larger concerns over immigration and naturalization. Opponents of Japanese immigration and naturalization referred to their supposed unassimilability. The loudest cries for exclusion came from California and Washington. The San Francisco Call editorial board opined that, "The National body politic can assimilate the European of whatever grade, but never the Asiatic. They are aliens always," and Roosevelt's "proposition to naturalize them is preposterous." ${ }^{47}$ Washington Governor Albert Mead stated, "Naturalization of the Japanese would tend to degrade the American workman" because "the two races will not assimilate." Kahn declared that Japanese would always remain loyal to Japan and "the oath of naturalization would be to them a hollow mockery."49 The Oregonian criticized extreme opinions and actions; for example, when anti-Japanese sentiments turned violent in a Tacoma, Washington suburb, an editorial said the Japanese had not offended anyone nor deserved such treatment. "Race prejudice is human," the editorial stated, but "lawlessness such as disgraced the town of Alder is intolerable. Even the little brown man is entitled to a square deal, " said the editors, trying to defend the Japanese while offending them at the same time. ${ }^{50}$ President Roosevelt's December 1906 message had been praised in the

46 "Immigration Real Question: Wheeler Says That It Must Be Settled In Co-operation With Japan," Oregonian, December 6, 1906, 4.

47 Barkan, From All Points, 132.

48 "Wants No Japanese Citizens: Mead Declares Opposition to Naturalization Bill," Oregonian, December 6, 1906, 4.

49 "Will Never Mix With Japanese: Kahn Voices California's Opposition to the Brown Orientals Fears Not War With Japan,” Oregonian, December 12, 1906, 2.

${ }^{50}$ Untitled editorial, Oregonian, December 7, 1906, 10. 
Japanese press, but now the same newspapers published the anti-Japanese outcry in California. ${ }^{51}$ The possibility of war was mentioned in both countries. Hoping to avoid conflict with Japan, Roosevelt negotiated a settlement: the San Francisco school board ended its segregation policy but the Japanese government promised to limit emigration on its end. ${ }^{52}$ This so-called "Gentleman's Agreement" decreased the flow of male laborers into the United States, but did not prevent the emigration of young "picture brides," Japanese women who became legally married to absentee husbands, to join the men already in America. ${ }^{53}$

In January 1907, California Republican state senators adopted a resolution protesting against the naturalization of Asians, while their Democratic counterparts adopted a resolution declaring that the president's interference in the school question violated state rights. ${ }^{54}$ In the spring the California legislature passed a joint resolution resolving that "we most strenuously oppose the proposition to naturalize Japanese and extend the elective franchise to the alien born of that race as being inimical to the welfare of the American people" and instructing the Congressional delegation to "combat such pernicious legislation." 55

Around this time the large majority of Japanese immigrants to the United States and their families lived in California. The Japanese community in

\footnotetext{
${ }^{51}$ Chuman, The Bamboo People, 28.

52 Ibid., 31-32.

${ }^{53}$ Ibid., 36.

54 “Asiatic Races Excluded: California Legislators Would Deny All Citizenship Rights," Oregonian, January 25, 1907, 1.

55 "Exclude Yellow Races: California Senate Opposes Granting Citizenship to Japanese," Oregonian, March 10, 1907, 8.
} 
California was more than twenty-five times as large as that in Oregon in $1910 .^{56}$ This may explain why the outcry against Japanese immigration and naturalization was limited in Oregon. In Oregon, the majority of Japanese immigrants had been contract laborers, mostly working for railroads, canneries, and timber companies. In the early twentieth century, however, many Oregon Japanese, as elsewhere on the West Coast, began to settle down and lease or buy their own farmland. ${ }^{57}$ Japanese farming communities began in eastern Portland and Multnomah County, notably in Montavilla, Russelville, Gresham, and Troutdale, as well as in Hood River. Anti-Japanese activity was minor in Oregon at this time, but Oregonian editorials and letters to the editor reflected some fear of an influx of Japanese immigrants.

\section{Lingering questions and concerns}

Confusion over eligibility persisted as Japanese immigrants continued to petition for citizenship. The Oregonian noted a pending case in Los Angeles County and quoted the applicant's lawyer saying, "It is my opinion that the Japanese can be naturalized if they want to make a fight for it." ${ }^{258}$ Before 1909, there were twelve cases in higher courts where people of many different backgrounds argued that they met the definition of white racial identity necessary for citizenship. ${ }^{59}$ Three of those cases involved Japanese immigrants, who were denied. However, before 1906, a few hundred Japanese immigrants did receive

\footnotetext{
${ }^{56}$ Census bureau statistics indicate that there were 1,461 Japanese people living in Oregon in 1910, when 41,356 Japanese people lived in California. From Azuma and Daniels.

${ }^{57}$ Azuma, “A History of Oregon's Issei," 329.

58 “May Make Japs Citizens,” Oregonian, May 16, 1907, 5.

${ }^{59}$ Barkan, From All Points, 135-136.
} 
naturalized citizenship in lower courts. ${ }^{60}$ One line of reasoning in support of granting citizenship can be seen in a July 1907 letter to the editor of the New York Times suggesting that alien Japanese were "a constant menace to the friendly relations that should be preserved, and for that reason the fewer alien Japanese we have in this country the greater the assurance of continued peace." ${ }^{\prime 61}$ A letter to the editor in the Oregonian demonstrated the confusion regarding current laws. The writer asked whether a "Chinaman or his son" can become citizens, to which the editor cited the 1906 Naturalization Act and replied that Chinese were not eligible, nor were "Japanese, Malay, and Mongolians," but that a child born in the U.S. of an alien of any of those nationalities was an American citizen. ${ }^{62}$ Of course, the former issue had not been definitively settled.

The issue concerning Japanese immigration that the Oregonian editorials focused on most in 1907 and 1908 was intermarriage. When the Japanese ambassador suggested that a good solution to the racial problems between Japanese immigrants and whites in the United States was intermarriage, ${ }^{63}$ the Oregonian responded immediately with an editorial criticizing the ambassador's ignorance and asserting that if intermarriage was the only solution, "there will be no peace. ${ }^{964}$ Over the next few months the Oregonian continued to opine against "race mixing," claiming that Japan should understand. Though at times race

${ }^{60}$ Ibid., 217.

61 “Make Japanese Citizens,” New York Times, July 14, 1907, 6.

62 "Aliens and Citizens: Questions About United States Naturalization Laws Answered," Oregonian, August 14, 1907, 8.

63 “Aoki Urges Intermarriage," Oregonian, July 14, 1907, 1.

${ }^{64}$ Untitled editorial, Oregonian, July 15, 1907, 6. 
prejudice could be "repulsive," one editorial explained, it was "the most powerful barrier against the amalgamation of races separated by distinction of color and there is no absurdity in the supposition that it was implanted for the prevention of race degeneration." ${ }^{95}$ The paper reported that a Japanese man from Tokyo wanted to send 10,000 American women to Japan to marry Japanese men and help ease tensions between the two countries. ${ }^{66}$ This report, as well as several stories about an influx of Japanese veterans in Mexico (either to circumvent immigration restrictions on Japanese laborers or to form an army to attack and invade the U.S.), likely inspired the next round of editorials. ${ }^{67}$ The Oregonian editorial board complained that it was too easy for Japanese laborers to enter the United States and that Americans in the eastern part of the country did not understand the problem. ${ }^{68}$ Another editorial expressed worry that Canada would tighten its laws, leaving the U.S. vulnerable to even more Japanese immigration, and again stated that easterners could not understand, because European immigrants in the east could easily assimilate, while "the yellow races can no more become blended with

65 “Japan Doubtless Will Understand," Oregonian, August 25, 1907, 8.

66 "Want American Brides Japanese Arranging For Emigration," Oregonian, November 2, 1907, 18.

67 "Waiting to Cross Borderline: 4000 Japanese in Mexico Waiting to Come Into United States," Oregonian, July 1, 1907, 9; "Flocking Over Border: Japanese Violate Immigration Law by Coming Through Mexico," Oregonian, July 5, 1907, 4; "Japanese Ready To Fight America: Hordes of Brown Men in Mexico," Oregonian, July 14, 1907, 1; “Army Dwindles to 400: Mexican Colonel Punctures Story of Japanese Invasion," Oregonian, July 17, 1907, 2; “Japanese Flock Across Border: Thousands Landing in Mexico Then Stealing Into United States: Getting Ready for War," Oregonian, July 27, 1907, 14, "Japanese Evade the Law: Get Passports To Go To Mexico But Stay in the United States," Oregonian, September 15, 1907, 4; "Uncle Sam Has Cause to Worry: Japanese Pouring In Over Border In Such Vast Numbers As To Create Alarm," Oregonian, October 7, 1907, 4.

68 "The Japanese Puzzle," Oregonian, November 16, 1907, 8. 
white than oil can mix with water." ${ }^{99}$ Yet another editorial accused Japan of being too sensitive on the immigration issue, stating, "We are not raising any question of inferiority or superiority," but "we simply do not want them in numbers among us, because of racial and economic differences." 70

The Oregonian editors had expressed anti-Japanese sentiments before; however, as the cry for total Japanese exclusion grew louder in California, the Oregonian editorial board seemed to change its tone. ${ }^{71}$ In late 1908 and early 1909 , the paper published a series of editorials on the topic of Japanese immigration, some of which were less critical than before. An editorial in October 1908 pointed out that recently more Japanese had left the U.S. than entered it and mocked the "phantom labeled 'Yellow Peril,", calling it "more imaginary than real." ${ }^{, 72}$ The editors noted that farm labor was needed and if Americans won't do it then "they are to blame." A month later, the editorial board switched back to a more familiar tune to object to the idea of "indiscriminate granting of American citizenship to those who desire to become citizens in name only," suggesting that Asians fit this category and should thus be barred from citizenship. ${ }^{73}$ However, a month after that, the Oregonian board defied the exclusionists to denounce the proposed alien land bill in California. ${ }^{74}$ Such flipflopping on the Japanese immigrant situation may suggest tensions amongst the

\footnotetext{
69 “Misunderstood Race Problem," Oregonian, November 29, 1907, 10.

70 "Needlessly Sensitive," Oregonian, January 11, 1908, 6.

71 "Shut Out Asiatics: California Democrats Want Total Exclusion," Oregonian, September 5, $1908,5$.

72 "Keeping Out The Japanese," Oregonian, October 16, 1908, 10.

73 "Barring the Undesirables," Oregonian, December 11, 1908, 10.

74 “Anti-Japanese Bills," Oregonian, January 21, 1909, 8.
} 
Oregonian's editorial staff.

\section{California's Anti-Japanese Campaign}

After the Gentlemen's Agreement promised slow down of Japanese immigration to the United States, anti-Japanese exclusionists in California were not satisfied. As Japanese women began arriving and more Japanese men settled down to farm with their new families, the exclusionists hoped to both end future immigration and thwart the progress of Japanese already residing in California. A bill introduced in January 1909 to require land-holding immigrants to apply for naturalization or give up their leases was intended to impact Japanese farmers, who were usually deemed ineligible for citizenship by the courts. The Oregonian responded by saying that "enlightened policy makes no objections to the ownership of land or any other property by aliens," adding that immigrants who invested capital in the communities in which they lived were a good thing, and that California "has nothing to gain by stirring up hostility with Japan, while there is much to lose by it." ${ }^{, 75}$ The next month, the Oregonian again scolded California's efforts to target its Japanese immigrants, saying that if California had to fight Japan alone, "we would see a very different spirit here" and "all these no valiant men would be exceedingly obsequious to Japan, for Japan could maul these states to a jelly in four months, and would probably do it." ${ }^{.76}$ This suggests that the Oregonian's position on the issue was largely tied to foreign policy concerns.

\footnotetext{
${ }^{75}$ Ibid.

76 "Baiters of the Japanese," Oregonian, February 6, 1909, 8.
} 
While some Oregon legislators favored legislation similar to the California law, most representatives in the state legislature as well as Oregon's congressional delegation preferred to leave the matter to Congress and the President, fearing that such state action could provoke war with Japan. ${ }^{77}$ Roosevelt persuaded California's governor to prevent the legislature from passing this alien land bill, temporarily blocking the exclusionists. ${ }^{78}$ The Oregonian commended the President, calling him a "man of peace, not an advocate of war."79 In a follow-up editorial, the Oregonian predicted, "With our vast superiority of resources we should wear Japan out, but we should suffer terrible humiliations first and enormous loss of property." 80

Around the same time, lest anyone think the Oregonian was pro-Japanese, an editorial commented on a Japanese man and his white American wife moving to Oregon, calling it revolting and the couple in question "perverts." 81 Oregon law at the time did not specifically prevent mixed marriages involving Japanese (laws did prevent whites from marrying blacks, Native Americans, or Chinese, however), but this unusual alliance must have sparked many a white Oregonian's most racist fears. ${ }^{82}$ The Oregonian also reported that pastors in Portland would

\footnotetext{
77 “Oregon Shies At Japanese Issue: Legislature Favors Leaving Settlement of Matter Entirely to Congress," Oregonian, February 9, 1909, 6.

${ }^{78}$ Roger Daniels, The Politics of Prejudice: The Anti-Japanese Movement in California and the Struggle for Japanese Exclusion (Berkeley: University of California Press, 1962), 47.

79 "Roosevelt Knows Strain is Tense: Single Misguided Act Might Force Rupture With Nippon, In His Opinion," Oregonian, February 15, 1909, 4.

80 "The United States and Japan," Oregonian, February 16, 1909, 8.

81 "A Disgusting Spectacle," Oregonian, March 26, 1909, 10.

82 "An Act To Prohibit Amalgamation and Intermarriage of the Races," Oregonian, November 2, 1866.

http:/www.ohs.org/education/oregonhistory/historical_records/popup.cfm?doc ID=16F99FADAADF-7E49-C10198BB87555DF6 Oregon repealed all anti-miscegenation laws in 1951, sixteen
} 
refuse to marry Japanese to whites and that Oregon judges would likely refuse such licenses. ${ }^{83}$ The Oregon legislature did consider a bill banning all mixed marriages in 1911 but it failed, despite crowds of protesters in Salem. ${ }^{84}$

Meanwhile, the Oregonian continued to publish editorials against miscegenation. In 1912 an editorial reported that five white women married to Japanese men in California allegedly went insane, calling it "shocking, but not surprising." 85 The Oregonian specifically criticized the union of white women and Japanese men, claiming that such marriages were more "examples of concubinage than marriage" because Japanese men were incapable of being loving husbands or fathers. ${ }^{86}$

The Oregonian followed with great interest a 1909 case that aimed at defining who was ineligible for citizenship. ${ }^{87}$ Namyo Bessho, who served in the U.S. Navy, appealed to a higher court after a judge in Virginia denied his citizenship petition. ${ }^{88}$ After losing his appeal in November, Bessho again appealed. ${ }^{89}$ Finally, Bessho was denied citizenship by the U.S. Circuit Court of

years before such laws were ruled unconstitutional by the U.S. Supreme Court in Loving $v$. Virginia.

83 "Pastors Would Refuse to Marry Japanese to White Persons," Oregonian, August 15, 1909, 2.

84 "Intermarriage Not Taboo: Bill is Killed in House at Salem, Amid Protesting Storm," Oregonian, February 19, 1911, 1.

85 "Tragedies of Intermarriage," Oregonian, June 30, 1912, 6.

86 "Intermarriage and Race Prejudice," Oregonian, August 4, 1912, 6.

${ }^{87}$ The Oregonian did not mention, however, the case of Buntaro Kumagai, who filed for naturalization as an honorably discharged soldier in the U.S. army, claiming that an 1862 law as well as the 1901 law allowed any such alien to naturalize. He was denied citizenship by a District Court judge in Washington state. This case is mentioned in Frank Chuman's The Bamboo People, 67-8.

88 "Japanese Denied Citizenship: Court Holds Chief Steward in Navy Not Entitled To Papers," Oregonian, May 5, 1909, 5.

89 "Is Japanese White Man? Fine Point Involved in Virginia Naturalization Case," Oregonian, November 27, 1909, 1. 
Appeals in February $1910 .{ }^{90}$ The question of whether military service merited naturalization privileges would come up in the courts again after the First World War, and, after the Second World War, would contribute to the elimination of the racial bar to citizenship.

Another complicating factor in the quest for citizenship was the status of family members. The Expatriation Act of 1907 had established that a woman who married a foreigner gave up her citizenship and took her husband's. ${ }^{91}$ Thus a Japanese-American Nisei woman who married a Japanese Issei man would likely lose her birthright citizenship. Japanese immigrants were not the only ones wondering if they would be admitted to naturalized citizenship. A judge in Oregon questioned whether Taraknath Das, an immigrant applying in Coos County, could not be granted citizenship, despite the fact that he was East Indian. ${ }^{92}$ Das argued that, being born in British India, he was entitled to the same treatment as a British citizen. ${ }^{93}$

In March 1913, the Oregonian reported that the YMCA and the Japanese Association of Oregon had begun to teach an assimilation class for Japanese immigrants in downtown Portland. ${ }^{94}$ The reporter noted that "the eagerness of some of the foreign-speaking people to learn English and the American customs is

\footnotetext{
90 “Jap Can’t Be U.S. Citizen: Oriental, 'Tis Decided, Is Neither Black Nor White,” Oregonian, February 2, 1910, 1.

91 Barkan, 135.

92 "Hindu Case Puzzles: Right to Citizenship Question of Difficulty,” Oregonian, May 28, 1912, 14.

${ }^{93}$ Das would later help found the anti-British East Indian revolutionary Gadar Party, and also lose his U.S. citizenship after the 1923 Supreme Court ruling U.S. v. Thind. https://www.lib.washington.edu/exhibits/southAsianStudents/das.html 94 "Assimilation of New Residents To Be Task of YMCA Workers," Oregonian, March 23, 1913 , 10.
} 
almost pathetic," and that "in Oregon the immigration problem is not so great, so there is a good possibility of this program being successful.” The smaller population of Oregon's Japanese community was likely also a factor in the Oregonian's reaction to the renewed attempts coming up in California to deny Japanese immigrants the right to own land.

\section{State Laws Discriminate Against Aliens, Inflame Japan}

California again became the cause of tension between the U.S. and Japan in 1913. When Roosevelt had intervened in 1909 to prevent passage of an alien land law in the state, he told the governor that San Francisco would not be considered to host the 1915 Exposition unless anti-Japanese sentiment was under control. ${ }^{95}$ While the bill was taken off the table, the U.S. negotiated a new Treaty of Commerce and Navigation with Japan in $1911 .{ }^{96}$ Japan would continue to restrict emigration while the U.S. would not explicitly block immigration. However, with the treaty and Exposition site secured, California legislators again proposed the Alien Land Bill in 1913. The Japanese ambassador, Chinda Sutemi, expressed concern that the bill jeopardized or violated the new treaty, and indicated that he might press the U.S. government to amend its naturalization policies. ${ }^{97}$ However, the new Democratic administration of Woodrow Wilson could not persuade Republican Governor Hiram Johnson and legislature of

\footnotetext{
${ }^{95}$ Chuman, The Bamboo People, 42.

${ }^{96}$ Ibid., 45.

97 "Japan Reserves Right To Protest: Wilson and Chinda Discuss Alien Bill," Oregonian, April 13, 1913, 1 .
} 
California to withdraw the bill. ${ }^{98}$

As during the 1909 debate, the Oregonian editors expressed disapproval of California going rogue and disrupting foreign relations with Japan. "Let California raise her own war funds, marshal her own armies, and, unaided, withstand the hosts of invading Japanese in the remote event that real trouble should follow," one editorial stated. ${ }^{99}$ The Oregonian reported that public pressure in Japan urged retaliation for the offense from California. ${ }^{100}$ On the same day, a new editorial suggested that the possibility of war might be averted if Californians simply stopped buying Japanese produce. ${ }^{101}$ This stance suggests that the Oregonian board harbored similar prejudice against Japanese immigrants but mainly disapproved of the California law because it created an international crisis. The next day the Oregonian again expressed hope that California would drop the controversial alien land law, stating that while "it is hardly admissible that 41,000 Japanese in a state having a total population of $2,377,549$ are a great menace to any occupation," and that the Gentleman's Agreement was slowing down Japanese immigration, perhaps even more stringent immigration laws could appease the exclusionists without risking war with Japan. ${ }^{102}$ (The editorial did not, however, explain how an immigration restriction would be less offensive to Japan than an alien land law.)

Whereas throughout most of the first decade of the twentieth century the

\footnotetext{
${ }^{98}$ Chuman, The Bamboo People, 48.

99 "Let California Try It," Oregonian, April 10, 1913, 8.

100 "Japanese Populace Biter: Newspapers Outline Plan to Seize Hawaii and the Philippines," Oregonian, April 19, 1913, 4.

101 "The Jap and His Produce," Oregonian, April 19, 1913, 8.

102 "The Root of the Trouble," Oregonian, April 20, 1913, 6.
} 
anti-Japanese movement in Oregon was weaker than in its neighboring states, exclusionist feelings were growing. One W.H. Gordon wrote a letter to the editor of the Oregonian, calling Asians "inferior to the Caucasian" and accusing the Japanese of wanting to intermarry with whites. ${ }^{103}$ "The pure Caucasian has a repugnant antipathy to intermixing with any of the colored races," he said, and the Japanese "should be barred from citizenship and ownership of our land."104 The letter suggested that the Japanese were already preparing to invade the United States as leaders of a pan-Asian movement and that Americans outside of the West Coast did not understand the situation. That the Oregonian would publish such a long letter may reveal sympathy with the anti-Japanese movement. However, while the Oregonian editors were generally "opposed to the orientalization of this or any other section of America," they did not believe "that there is at this time serious cause to fear that undesirable condition." ${ }^{105}$ A stronger position against the anti-Japanese hysteria was taken by the Portland Chamber of Commerce, which passed a resolution denouncing "any action tending towards discrimination unfavorably against the Japanese of California," and urging the California legislature to "avoid such action or any other action that will tend toward injuring trade relations between this country and Japan."106

The California Alien Land Bill greatly upset the Japanese government, which stated that the 1911 treaty gave them "most favored nation" status and

103 "This Is White Man's Country: Japs Are Too Arrogant and Must Be Tamed One Day," Oregonian, April 30, 1913, 10.

104 Ibid.

105 "Checking the Yellow Peril," Oregonian, May 3, 1913, 10.

106 "Portland Takes Issue: Chamber of Commerce Deprecates Action Affecting Japan Trade," Oregonian, April 19, 1913, 12. 
equal treatment with other immigrants. ${ }^{107}$ To avoid further tensions, Tokyo Mayor Baron Sakatani suggested that naturalization rights for Japanese immigrants in the U.S. should be guaranteed ${ }^{108}$ An editor of a Tokyo newspaper also advocated for a campaign to obtain naturalization privileges. ${ }^{109}$ (Meanwhile, Sam Inoo, a Japanese man living in Joseph, Oregon, applied for citizenship in Wallowa County. ${ }^{110}$ His fate is unknown.) The Japanese government believed the California bill violated the spirit of the 1911 treaty. ${ }^{111}$ As in 1909, both countries spoke of war, but hoped that tensions could be eased diplomatically. The Oregonian reported that officials in Tokyo acknowledged that the situation could lead to estrangement between the two countries. ${ }^{12}$ Secretary of State William Jennings Bryan responded to Japan's protest in efforts to calm fears. ${ }^{113}$ However, some lawmakers outside of the West were backing California's right to enact alien land laws. Mississippi Representative Thomas Sisson, for example, gave a speech defending California which the press portrayed as unlikely to offend Japan. ${ }^{114}$

\footnotetext{
107 “Treaty Is Quoted: Japan Resents Being Placed In Inferior Position,” Oregonian, May 7, 1913, 7. ${ }^{108}$ Ibid.

109 "Japanese Concerned Over Race Outlook: Tokio Editor Advises People to Seek Naturalization In Other Countries," Oregonian, July 20, 1913, 5.

110 "Naturalization is Asked: Joseph Man From Japan Desires To Become An American," Oregonian, May 9, 1913, 2.

111 “Japan Situation Becomes Tense: Tokio's Attitude Remains in Doubt," Oregonian, May 19, $1913,1$.

112 "Tokio Still Shows Faith: Likelihood of Estrangement of Peoples, However, Admitted," Oregonian, May 19, 1913, 2.

113 "Note Calms Japan, Washington Hears: Friendly Spirit of America's Reply Strikes a Responsive Chord at Tokio," New York Times, May 22, 1913, 2.

114 "Sisson Puts State Above All Treaties: No Nation Can Dictate Land Laws To Us, He Tells the National House," New York Times, May 24, 1913, 2.
} 
The Oregonian reported that the federal government might decide to take the California law to court, in which case the Supreme Court might finally rule on the question of Japanese naturalization. ${ }^{115}$ An editorial recommended that the Supreme Court was indeed the correct branch of government to solve the issue. ${ }^{116}$ However, the paper published a lengthy letter to the editor by an anonymous reader in southern Oregon saying that a new legal definition of white would not be acceptable to people on the West Coast and that the Japanese were simply unassimilable. ${ }^{117}$ The writer especially objected to intermarriage between whites and Japanese, an opinion shared by most of the Oregonian editors.

Observers outside the U.S. and Japan paid attention to the growing conflict. A Canadian newspaper reported that a delegation from Tokyo traveled to California with demands for a new naturalization law. "According to the best informed opinion here," the Regina Leader noted, "the Japanese will suffer a rude awakening if they venture to raise the question of citizenship," because "such a demand... would arouse a tremendous opposition... It is believed here that the Japanese people are unaware of the popular opposition such a demand as is proposed would arouse in the United States." ${ }^{118}$ The U.S. looked to Canada for a solution to the crisis, according to the Oregonian, as Canadian laws prevented Japanese immigration (with exceptions for students and travelers) but their actions

\footnotetext{
115 "United States May Oppose California: Treaty Rights of Japanese At Issue," Oregonian, April 20, 1913, 1 .

${ }^{116}$ Untitled editorial, Oregonian, May 20, 1913, 8.

117 "Japan Not In Racial Sympathy: California Issue Will Not Be Settled by the Technical Definition," Oregonian, May 23, 1913, 10.

118 "Japan To Make More Demands: Administration Fears She Will Ask For Full Citizenship," The Morning Leader, May 25, 1913.
} 
had not provoked objections from Tokyo. ${ }^{119}$

The California Alien Land Act became law in 1913 and, although a crowd of twenty thousand in Tokyo cheered the suggestion to send the Imperial Navy to California to protect its citizens, war did not follow. ${ }^{120}$ To try to get around this newly encoded racism, the Issei now transferred land titles to their American-born children. ${ }^{121}$ The Japanese immigrant community also increased efforts to win naturalization rights, and thereby negate discriminatory land laws and improve foreign relations. Influenced by this campaign, the Oregonian began to take a new position on the subject of Japanese naturalization. However, many exclusionists also increased their anti-Japanese campaign, including a growing number of whites in Oregon.

\footnotetext{
119 “Japan's Answer To Be Ready Soon: Resort to Naturalization Laws for Relief Now Believed Improbable," Oregonian, June 1, 1913, 6.

${ }^{120}$ Walter LaFeber, The Clash: U.S.-Japanese Relations Throughout History (New York: Norton, 1997), 105-106.

${ }^{121}$ Johnson, “Anti-Japanese Legislation in Oregon,” 202.
} 


\section{Chapter 3: Oregonian Support for Naturalization and Appeals to Federalism (1913-1924)}

After the passage of the 1913 Alien Land Act in California, there was a lull in the anti-Japanese movement but an increase in the efforts of the Japanese community and its allies to campaign for naturalization and immigration rights. ${ }^{122}$ Two people that increased their advocacy for Japanese immigrants and appeared to have an impact on the Oregonian editorial board were the Japanese journalist Kiyoshi Kawakami and the American missionary Sidney Gulick. Over the next decade, both men saw their work published in Portland and some of their ideas espoused in editorials. The issue of naturalization gained heightened importance because the right to make a living was now threatened by state laws excluding immigrant land ownership on their assumed ineligibility for citizenship. The Oregonian expressed some support for Japanese naturalization while at the same time deferring to the federal government and supporting immigration restrictions. The federal government weighed in both judicially and legislatively in the early 1920s.

\section{A New Spokesperson}

In August 1913, the Oregonian reported that the Japanese in California had hired Kiyoshi Kawakami, "a newspaperman with training on both sides of the Pacific... to correct in this country what the Japanese feel is a growing misconception of themselves as a people," hoping that positive publicity would

${ }^{122}$ Daniels, The Politics of Prejudice, 79. 
help combat anti-Japanese sentiments as well as "promote international friendship." ${ }^{23}$ Kawakami was born in Yamagata prefecture in Japan and came to the United States as a student in 1901 when he was twenty-two. ${ }^{124}$ He directed the Pacific Press Bureau, a news agency run by the Japanese foreign ministry, from 1914 to 1920 . In this role, he argued that the Japanese could be assimilated into American culture and should be deemed eligible for naturalization.

A review of Kawakami's book, Asia at the Door, appeared in the Oregonian in April 1914. The reviewer praised Kawakami for presenting "the side of Japan with untiring industry, plausibility, and courage." ${ }^{125}$ In the book, Kawakami pressed for naturalization rights by arguing that Japanese were of Aryan origin like Europeans and indicated that Japan would prevent the emigration of an "undesirable class." The reviewer did not agree with all of Kawakami's points (for example, implying some shock at Kawakami's suggestion that more Japanese should marry Americans), but left the reader with the assessment that the book would be "noticed" and "provoke controversy."

In November 1914, Oregonian readers saw the first of three op-ed pieces written by Kawakami. In it, Kawakami urged Americans to increase trade with Asia, pointing out that the war in Europe had disrupted Asian-European trade and thus created an opportunity for American businesses, and reminding readers that

\footnotetext{
123 "Japanese Cause Aided: California Nipponese Hires Trained Press Agent," Oregonian, August 8, 1913, 4.

${ }^{124}$ Yuji Ichioka, The Issei (New York: The Free Press, 1988), 190.

${ }^{125}$ Book Review of Asia at the Door, Oregonian, April 12, 1914, 11.
} 
Japan was allied with Britain. ${ }^{126}$ Three months later Kawakami lobbied again for the U.S. to trade with Asia. ${ }^{127}$ These articles were likely syndicated and published in papers around the country in an effort to win allies for the Japanese community and Japan. A third appeared in October, in which Kawakami responded to a book published in translation by California newspaperman William Randolph Hearst. ${ }^{128}$ Hearst presented the book, titled The Dream Story of an American-Japanese War, as coming from a group associated with Japanese politicians, and thus representative of sentiments held by many in the Japanese government.

Kawakami claimed that Hearst lied about the authorship of the inflammatory book, trying to present certain Japanese politicians as war mongers, when in fact the book did not reflect official Japanese policy, just as provocative writings by Americans meant to incite war against Japan did not reflect the wishes of the U.S. government. That the Oregonian gave Kawakami the platform to advocate for Japan may suggest that there was some support for his ideas amongst the editors.

\section{World Peace Movement Weighs In}

In late 1915, a speaker in Portland drew the attention of the Oregonian editorial board. Sidney Gulick, a missionary in Japan and representative of the Federal Council of Churches, traveled the U.S. making speeches on U.S.-Japan relations and U.S. immigration and naturalization policy. ${ }^{129}$ Gulick spoke to the

\footnotetext{
${ }^{126}$ K.K. Kawakami, “America’s Export Opportunity: Japanese Author Sees Great Trade Possibilities in Orient," Oregonian, November 11, 1914, 10.

${ }^{127}$ Kawakami, “America Urged To Go Into Orient For Trade,” Oregonian, February 14, 1915, 10.

${ }^{128}$ Kawakami,"Hearst Story Is Denounced: Japanese Throws New Light On Supposed War Forecast," Oregonian, October 17, 1915, 9.

${ }^{129}$ Sandra C. Taylor, "The Ineffectual Voice: Japan Missionaries and American Foreign Policy, 1870-1941," Pacific Historical Review 53 (1984): 24.
} 
Portland Chamber of Commerce and recommended that the racial bar to citizenship be eliminated and an immigration quota based on current population applied equally to all nationalities. ${ }^{130}$ The newspaper endorsed Gulick's plan, stating that "we exclude all Chinese and Japanese except a limited class, while admitting persons of other nations who are far more objectionable than would be many of the Chinese and Japanese," and recognized that U.S. policy caused "resentment which seriously mars the harmony of international relations." ${ }^{\text {"131 }}$ That the Portland Chamber of Commerce endorsed Gulick is not surprising, given their earlier denunciation of the anti-Japanese movement, but this marked a turning point for the Oregonian regarding the issue of Asian American citizenship. One explanation may be that, while supporting Japanese naturalization, Gulick was also opposed to miscegenation and also favored immigration restrictions, two positions which the Oregonian editors had also expressed. ${ }^{132}$

Gulick had been writing about his immigration plan since 1914. "We must abandon all differential Asiatic treatment," he implored. ${ }^{133}$ In 1916 he further explained how his plan would achieve the dual goals of preventing a flood of Asian immigration while improving foreign relations by eliminating humiliating race discrimination. ${ }^{134} \mathrm{He}$ warned, "If Asia fears and distrusts

130 "Citizenship Plan New: Admission Of All On Reasonable Basis Is Advised," Oregonian, November 23, 1915, 15.

131 "A New Immigration Policy," Oregonian, November 26, 1915, 8.

${ }^{132}$ Daniels, Politics of Prejudice, 80.

${ }^{133}$ Sidney L. Gulick, The American Japanese Problem (New York: Charles Scribner's Sons, 1914), 284.

${ }^{134}$ Sidney L. Gulick, "What Program Shall the United States Stand For in Her Relations with Japan and China? The Problem and A Practical Solution," Annals of the Academy of Political and Social Science 66 (1916), 112. 
Christendom because of continued injustice, Asia will arm." ${ }^{135}$ In order to foster peace between the U.S. and Japan, Gulick lobbied for a new immigration and naturalization plan for two decades. While his popularity with the Oregonian editorial board shows his influence, biographer Sandra C. Taylor wrote that ultimately his voice was much weaker than "Japanophobes like V.S. McClatchey and William Randolph Hearst" who, as newspaper publishers, "had greater access to the press." ${ }^{136}$ Gulick argued the importance of reforming American naturalization law as a means to heal the great injury done to Japan by denying citizenship to Japanese immigrants, which he later described as "far more serious than is generally realized." $" 137$

\section{War Talk}

On both sides of the Pacific, talk of war between the United States and Japan surfaced each time there was a surge in the anti-Japanese movement: the 1906 San Francisco school crisis, the proposal of an alien land law in California in 1909 , and the passage of the law in 1913. To some extent, speculation of a U.S.-Japan war continued even after the outbreak of World War I, despite the fact that Japan was allied with Great Britain. In 1916, Jinji Kasai, editor of the Pacific Press of San Francisco, spoke at a Portland Chamber of Commerce luncheon and warned that it was "not a wise thing to speak of a friendly nation as a possible

\footnotetext{
${ }^{135}$ Ibid., 116.

136 Taylor, "The Ineffectual Voice," 26.

${ }^{137}$ Sidney L. Gulick, "American-Japanese Relations: The Logic of the Exclusionists," Annals of the American Academy of Political and Social Science 122 (1925), 186-187.
} 
enemy." ${ }^{138}$ B. Takita, editor of the Japanese-language Oregon News, wrote a letter to the editor of the Oregonian regarding the Mexican Revolution and some press speculation that Japan was interfering in Mexico against the interests of the United States. ${ }^{139}$ While the main topic of the letter was based on foreign relations, he also wrote that, while "it is true that there are some unfriendly feelings toward the local Japanese along the Coast... time will prove us good citizens." Later that year, the Oregonian reported on another visiting Japanese spokesperson, journalist Kayan Kayahara, who declared that Japan had no intentions of expansion onto the American continent. ${ }^{140}$ Kayahara again dispelled alleged rumors of Japanese aims to take territory in Mexico. ${ }^{141}$

Even after American entry into the war in 1917, tensions between the U.S. and Japan continued. That year, the Japanese navy adopted a policy viewing the U.S. as an enemy. ${ }^{142}$ Japanese Navy Minister Kato Tomosaburo cited five American policies that contributed to the hostility: the Monroe Doctrine, exclusionist immigration policy, the Open Door policy in China, opposition to Japanese expansion goals, and naval build up. ${ }^{143}$ The war slightly cooled antiJapanese sentiments in the U.S., but the question of naturalization and future

\footnotetext{
138 "Japanese is Critic: Preparedness Attitude of This Country Declared Faulty," Oregonian, May $2,1916,13$.

139 "Japan Is Declared Friendly: B. Takita Says Reported Aid to Carranza is Ridiculously Absurd," Oregonian, June 24, 1916, 8.

140 "Noted Japanese Here: Kayan Kayahara, Journalist, Asserts Friendship of Nations," Oregonian, November 22, 1916, 13.

${ }^{141}$ This study could not find any other primary or secondary sources that discussed these claims, which suggests that there was not real evidence and that the Oregonian quietly dropped the subject.

142 Akira Iriye, Across the Pacific: An Inner History of American-East Asian Relations (Chicago: Imprint Publications, 1967), 131.

${ }^{143}$ Ibid.
} 
immigration restriction remained open.

\section{Citizenship Questions and Implications During the War}

Japanese immigrants continued to petition for citizenship during this time. The Oregonian described a white Japanese citizen, a Dutch-born woman divorced from her Japanese husband, as "the first Japanese citizen to ask for American naturalization with any prospect of getting it." ${ }^{144}$ This unusual case highlights the importance of race in the immigrant quest for American citizenship. Though other sources have mentioned that Japanese aliens were at times given citizenship, the Oregonian generally only reported failed petitions. ${ }^{145}$ This may indicate that those who did gain citizenship did not raise great concern. More newsworthy were the cases that were challenged, such as Takao Ozawa's 1917 appeal in California. ${ }^{146}$ Ozawa's case would reach the U.S. Supreme Court in 1922, attracting international attention, and the Court's decision would impact Japanese naturalization and immigration to the United States for the next thirty years.

Born in Japan, educated in California, and settled in Hawaii, Ozawa first applied for citizenship in 1914. When he was denied, he appealed to the Ninth Circuit Court of Appeals in 1916, attracting the attention of the Pacific Coast Japanese Association Deliberative Council. ${ }^{147}$ The council, formed of representatives from all the West Coast Japanese Associations, had convened in

\footnotetext{
144 “Japanese Citizen Applies: White Woman, Divorced From Oriental, May Get Papers," Oregonian, February 22, 1917, 1.

${ }^{145}$ Ichioka cites the 1910 census as indicating 420 naturalized Japanese Americans in The Issei, 211.

146 "Jap Demands Citizenship: Appeal Is First To Reach Federal Supreme Court in California," Oregonian, May 25, 1917, 3.

${ }^{147}$ Ichioka, The Issei, 221.
} 
Portland in 1913 and resolved to find a test case to take the issue of naturalization to the Supreme Court. Some Issei leaders favored using diplomatic pressure to gain naturalization rights, but the Japanese Foreign Ministry had made it clear it would not press the matter when it left naturalization out of the 1907 negotiations resulting in the Gentlemen's Agreement. Other Issei hoped for a congressional solution, but many feared that public opinion was against them and thus saw the courts as their best chance. The JADC hoped that a judicial solution was possible. Ozawa's case was forwarded to the Supreme Court but then put on hold for diplomatic reasons during the war, peace negotiations, and 1921-22 Washington Naval Conference. ${ }^{148}$ The Oregonian dropped its coverage of Ozawa's petition until it resurfaced in 1922.

Meanwhile, Oregon's first attempt to pass an alien land law modeled on the notorious California legislation occurred in 1917. Perhaps influenced by Gulick, the Portland Chamber of Commerce, as well as the U.S. State Department, persuaded the Oregon legislature to kill the bill rather than stir controversy with Japan, an ally in the Great War. ${ }^{149}$ Oregon legislators proposed another alien land bill during the next legislative session and again faced economic arguments put forth by the Portland Chamber of Commerce. This time the Oregonian also weighed in on the subject, declaring that as the bill intended to to hurt Asian immigrants, the effort was "peculiarly indelicate in view of recent, even present association with them in a world enterprise of vast consequence,"

\footnotetext{
${ }^{148}$ Ibid., 220-5.

${ }^{149}$ Daniel P. Johnson, “Anti-Japanese Legislation in Oregon, 1917-1923,” Oregon Historical Quarterly 97 (1996), 191.
} 
likely referring to the recently ended war and the just opened peace negotiations in Paris. ${ }^{150}$ The editorial condemned the bill, saying that "even apparently serious consideration of a bill such as this one may involve the nation in annoying and wholly unnecessary diplomatic complications" and "it would have the aspect of an intentional insult to peoples with whom we are on friendly terms and it would be construed by them as such."

Questions over naturalization law returned to the pages of the Oregonian when World War I veterans applied for citizenship in Oregon and elsewhere, although the eventual fate of these veterans was not published. ${ }^{151}$ Soldiers applied in Hawaii, hoping that a new 1918 law expediting citizenship for soldiers would aid their quest. ${ }^{152}$ A judge in Honolulu granted citizenship to Sachi Shimodo in January 1919 but the Assistant U.S. District Attorney appealed the decision. ${ }^{153}$ A judge in Texas later ruled that the 1918 naturalization law conflicted with the 1906 statute and thus denied citizenship to Japanese who had fought for the U.S. in the war. ${ }^{154}$ The Oregonian editorial board rang in on the controversy, re-endorsing Gulick's plan to allow for Asian naturalization while setting a quota based on current demographics to limit future immigration. ${ }^{155}$ Such a plan would "abolish all discrimination against those countries (Japan and

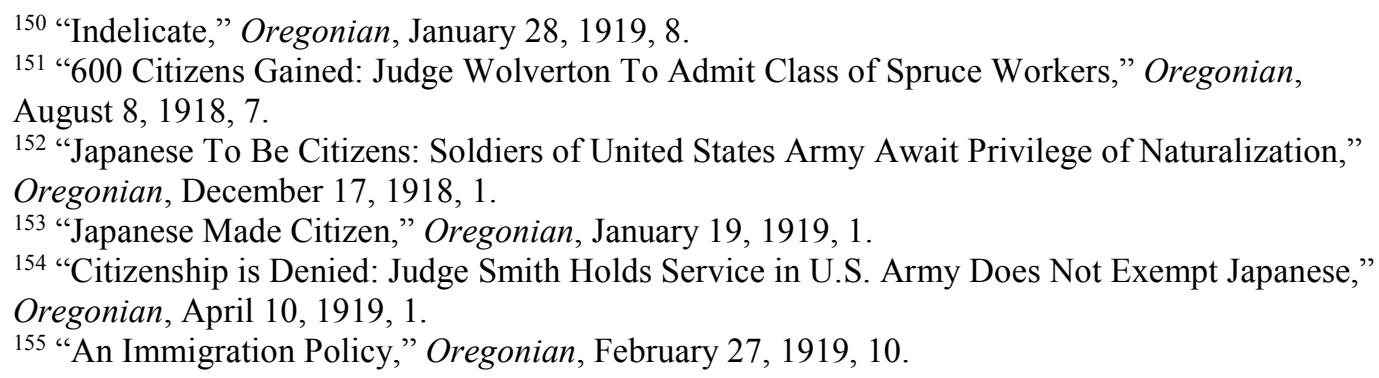


China) and thus end all cause of friction."

When Japan's ambassador at the Paris Peace Conference asked for racial equality, the Oregonian again echoed Gulick and called for an end to race discrimination in naturalization. ${ }^{156}$ An editorial denounced U.S. laws "framed as to put the brand of inferiority" upon Japanese, and advocated that "one of the chief merits of this plan (to allow naturalization while still limiting immigration) is that it meets the wishes of those who oppose Japanese, Chinese, and Hindu immigration and at the same time it meets the objections of those nationalities to present laws for their exclusion." Furthermore, the editors commented, "We should no longer deny citizenship to these races, while granting it to Tartars, Turks, Syrians, Hindus, Persians, Mexicans, Zulus, Hottentots, and Kaffirs.”157

\section{Post-war Rise in Hostility}

While the Oregonian editorial board expressed increased tolerance, antiJapanese sentiment in Oregon grew in the postwar period, as demonstrated by the Oregon Senate's unanimous passage in 1920 of Joint Memorial 1, which proposed an end to birthright citizenship (as guaranteed by the 14th Amendment and upheld by the U.S. Supreme Court) for children of aliens ineligible for citizenship. ${ }^{158}$ The Oregonian responded to the legislature with an editorial claiming that the resolution would not have any effect and that, unlike in California, Japanese

\footnotetext{
156 “Make The Law Same For All,” Oregonian, March 22, 1919, 8.

${ }^{157}$ Ibid.

158 "Session Expect To Finish Today: Day Is Unlucky for Aliens, Especially Japanese," Oregonian, January 17, 1920, 1.
} 
immigrants were not a problem in Oregon. ${ }^{159} \mathrm{~A}$ bill to bar aliens ineligible to citizenship from employment on public works was vetoed by the Oregon Governor Olcott in 1920; however, when California strengthened their alien land law that year efforts to do the same were renewed in Oregon. ${ }^{160}$ One of Oregon's U.S. senators, Charles McNary, telegrammed each state legislator, urging postponement of the measure. ${ }^{161}$ White Oregonians were obviously in conflict with each other over the future of their Japanese residents. Much of the most vehement anti-Japanese sentiment came from Hood River, where the Anti-Asiatic Association lobbied once more for an alien land law. ${ }^{162}$ The group wrote to Oregon political candidates but only 61 of 307 replied. All but one of these candidates shared the anti-Japanese sentiment, but the fact that most ignored the letter shows that the Japanese question was not an issue for all Oregon politicians.

The Oregon Journal newspaper reported in March 1920 that three Japanese immigrants were admitted as naturalized citizens in San Francisco when a Judge Rankin interpreted an act of May 9, 1919 to mean that any military veteran was eligible for citizenship. ${ }^{163}$ The article did not give the names of the new citizens, but did suggest that legal action might be taken against them.

In 1920 the U.S. House of Representatives held committee hearings on the West Coast on the subject of immigration and naturalization. In Stockton, California, the possibility of assimilation was debated, as Yo Suzuki, president of

159 "That Anti-Japanese Resolution,” Oregonian, January 23, 1920, 10.

${ }^{160}$ Johnson, “Anti-Japanese Legislation in Oregon," 192-194.

${ }^{161}$ Ibid., 194.

162 "Bill Aims At Japanese," Oregonian, February 2, 1920, 15.

163 "Three Japanese Are Admitted to Full Citizenship," Oregon Journal, March 3, 1920. 
the Stockton Japanese Association, said Japanese "can be assimilated and all our efforts are to become Americanized," while W.R. Jacobs, an attorney, demonstrated the fear of miscegenation that dominated the anti-Japanese exclusion movement when he argued that talk of assimilation would lead to "joy rides of big Japanese boys and American girls." ${ }^{.164}$ Others weighed in that Japanese fishermen posed a danger with their strong knowledge of the coastline, and that Japanese workers threatened American workers, although Japanese were barred from joining local unions. ${ }^{165}$ In San Francisco, the American Legion represented the anti-Japanese side, while Dr. Harvey Guy, a former missionary in Japan, spoke in favor of naturalization and assimilation. ${ }^{166}$ On the same day, the Oregonian reported that a Japanese man in Sacramento petitioned for a writ of mandamus on the grounds that as a veteran he earned the right to vote. ${ }^{167}$ The Judge denied his petition, but the Oregonian pointed out that the 1919 naturalization law said "any alien" who served in the armed forces was eligible for citizenship.

At another House hearing in Tacoma, Washington, Seattle Mayor Bert C. Ross testified for total exclusion and expatriation of citizenship from children of Japanese aliens. ${ }^{168}$ Anti-Japanese comments by Washington Representative

\footnotetext{
164 “Jap Assimilation In America Argued: 'We're Ready for Melting Pot,' Say Nipponese" Oregonian, July 17, 1920, 6.

${ }^{165}$ Ibid.

166 "Probers Plead For More Time: Committee Wants Diplomatic Solution of Japanese Problem," Oregonian, July 21, 1920, 3.

167 "Judge Denies Japanese Vote: Soldier of Hawaiian Infantry Loses Court Fight in California," Oregonian, July 21, 1920, 3.

168 "Citizenship Bar On Japanese Is Urged: Rigid Exclusion Advised At Tacoma Hearing," Oregonian, August 3, 1920, 4.
} 
Albert Johnson were publicized in Japan, increasing the bitterness felt by many there regarding American policy. ${ }^{169}$ That fall, an Oregonian article referred to the California Japanese Exclusion League as wanting to start a war. ${ }^{170}$ At a dinner of the Japanese Society in New York City, the president of U.S. Steel Corporation urged Americans to be calm, and the U.S. and Japanese ambassadors expressed hopes that misunderstandings would end. ${ }^{171}$

Back in Portland, another WWI veteran, who had been the victim of gas attacks, applied for citizenship. ${ }^{172}$ His petition was denied by U.S. District Judge Charles Wolverton, who told Sato that he personally wished to grant him citizenship but felt that a higher court must settle the matter. ${ }^{173}$ The answer would come from the U.S. Supreme Court two years later.

In 1921, the Oregonian maintained its limited support for Japanese immigrants, but another newspaper, the Portland Telegram, emerged as a loud voice against Japanese assimilation. The Portland Telegram had recently begun publishing a string of anti-Japanese editorials, urging the state legislature as well as the federal government to end Japanese immigration. ${ }^{174}$ Both these Portland newspapers reported on Governor Olcott's January 11th address to the legislature,

\footnotetext{
169 "Japanese More Bitter: Feeling Increased By Statement of Johnson," Oregonian, August 7, $1920,6$.

170 "California Starts Anti-Japanese War," Oregonian, September 3, 1920, 7.

171 "Gary Avers Japan Is Not Seeking War: If Clash Comes, U.S. Is Held Most To Blame," Oregonian, December 16, 1920, 6.

172 "Sato Seeks Citizenship: Japanese Veteran of U.S. Army Wants Honor," Oregonian, December $16,1920,6$.

173 "Citizenship in U.S. Is Granted to 48: Admission Refused to One Japanese Ex-Soldier," Oregonian, December 17, 1920, 14.

174 "The Real Japanese Problem," Portland Telegram, September 2, 1920; "Oregon and the Japanese Problem," Portland Telegram, January 7, 1921.
} 
in which he discussed several topics including Japanese immigration, claiming that the Japanese could never be assimilated into Oregon's culture (where "the pioneer blood flows more purely and in a more nearly undiluted stream than in any other state of the union") and that "the Japanese should work out his destiny in Asia," not America. ${ }^{175}$ The Oregonian's and Portland Telegram's respective editorials put the two newspapers on opposing sides of the Japanese question.

On the issue of the so-called "Japanese situation," which, although it was not the governor's first topic, was the first to be addressed in the I editorial, the editors disagreed with the governor's characterization of the current Japanese immigrant population as a threat to the state's interests. ${ }^{176}$ "Japanese colonization is not so great a menace that the problem cannot be taken up in a more leisurely and safer way than that suggested by the governor," the editorial insisted. The editors maintained their previous stance that the western states should not thwart the State Department's efforts to negotiate with Japan and suggested that California's anti-Japanese laws may not have been constitutional. Deferring to the federal government to handle issues with international implications was the Oregonian's stance as usual. The editors went further, however, showing more sympathy with the Japanese than they had previously, pointing out that Japan had an overpopulation problem yet faced hostility, both official and unofficial, from the United States in efforts to expand within the Asian continent. "The Japanese

\footnotetext{
175 "Oregon Is For Americans Only, Declares Olcott: Urges Legislative Members to Enact Laws Which Will Let the World Know Where We Stand On The Japanese Question," Portland Telegram, January 11, 1921; "Strict Economy Everywhere is Urged by the Governor," Oregonian, January $12,1921,8$.

176 “The Governor's Message,”, Oregonian, January 12, 1921, 12.
} 
can read therein only that powerful America would deny them access to the western hemisphere and deny them access to Asia" the Oregonian opined, continuing, "that it would confine them to their own islands and thereby deprive them of every chance of national development and national prosperity." "This editorial represented an unusual degree of disagreement with a Republican governor from a traditionally pro-Republican newspaper and was one of the Oregonian's strongest editorials in favor of Japanese immigrants.

On the other side of the spectrum, the Portland Telegram followed up reporting on the governor's address with an editorial advocating the passage of an alien land law in Oregon. ${ }^{178}$ Two months later, the Portland Telegram wrote that where there are Japanese people, “white people cannot live a white man's life."179 This editorial criticized Japanese cultural treatment of women and expressed fear of the so-called "Orientalization" of American civilization. In another editorial in November, the Portland Telegram opined that while the Japanese were better farmers than most Americans and could not be blamed for their success in the fields of Oregon, they remained unassimilable and therefore "they must not pass the bounds set by nature to divide these two good but unblendable races." "180

\section{Oregon Politics}

The November 1922 elections brought sweeping changes to Oregon's political leadership. Republican Governor Ben Olcott lost his re-election bid to

\footnotetext{
177 Ibid.

178 “Oregon Faces Japan,” Portland Telegram, January 12, 1921.

179 “The Japanese Among Us," Portland Telegram, April 11, 1921.

180 “Our Japanese Farmers," Portland Telegram, November 17, 1921.
} 
Democrat Walter Pierce, who, according to the Oregonian, won because he "bargained for the vote of the patriotic societies and ku klux and he got it."181 Oregon Republican C.N. McArthur lost his seat in the U.S. House of Representatives to Democrat Elton Watkins, the first Democrat to represent Oregon in Congress since $1879 .{ }^{182}$ One issue that brought more Democrats to the polls in Oregon that year was the Compulsory Education Bill, an initiative that required all Oregon children to attend private, not parochial, schools. The initiative, supported by most Democrats in the state, passed, against the recommendation of the Oregonian. ${ }^{183}$ The measure reflected the anti-foreigner mood that had been growing in the state. The Ku Klux Klan experienced "phenomenal growth" in Oregon since 1921, where "militant nativism" appealed to many despite the fact that the huge majority of the population were white Protestants and the numbers of Jewish, Catholic, and Asian newcomers did not make a big change in demographics. ${ }^{184}$ Nativist pressure may have influenced then-governor Olcott's earlier statements regarding Japanese immigrants, but the Oregon Klan was not convinced. The Klan successfully supported Democrats Walter Pierce, Elton Watkins, and several Democratic candidates for the state legislature. $^{185}$

\footnotetext{
181 “The Big Wind," Oregonian, November 9, 1922, 12.

182 "Multnomah Vote is Won by Pierce," Oregonian, November 9, 1922, 1.

183 "Education and the State," Oregonian, November 6, 1922, 10.

${ }^{184}$ Eckard Toy, "The Ku Klux Klan in Tillamook, Oregon,” The Pacific Northwest Quarterly, 53: 2 (April 1962), 60.

${ }^{185}$ David A. Horowitz, "The Klansman as Outsider: Ethnocultural Solidarity and Antielitism in the Oregon Ku Klux Klan of the 1920s," The Pacific Northwest Quarterly, 80: 1 (January 1989), 18.
} 


\section{U.S. v. Ozawa}

In 1922 the question of Japanese naturalization finally faced the U.S. Supreme Court. ${ }^{186}$ The immigration appeal of Takao Ozawa had been reported in the Oregonian in 1917, but the case had been delayed in its path to the nation's highest court. ${ }^{187}$ Ozawa's case, which had been selected by the Pacific Coast Japanese Association Deliberative Council as a test case, would determine whether Japanese immigrants could become U.S. citizens or not. Ozawa argued that he should qualify for citizenship based on his good character and devotion to his adopted country, declaring that, "In name, General Benedict Arnold was an American, but at heart he was a traitor," while Ozawa himself was "not an American, but at heart I am a true American."188 The hopes of the Japanese immigrant community rested on him, and he was seen as their best chance due to his morally clean lifestyle, Christian faith, English language skills, and Americanized children.

On November 13, 1922, Takao Ozawa was denied citizenship in a unanimous opinion written by Associate Justice George Sutherland. ${ }^{189}$ The justices agreed that the privilege of naturalization was intended by the founders for whites only, and that "white" should be defined as belonging to the Caucasian race. "The appellant," the ruling stated, "is clearly of a race which is not

\footnotetext{
186 "Right Of Japanese Citizenship Up: Case Before Supreme Court For Decision," Oregonian, October 4, 1922, 2.

187 "Jap Demands Citizenship: Appeal Is First To Reach Federal Supreme Court in California," Oregonian, May 25, 1917, 3.

${ }^{188}$ Ichioka, The Issei, 219.

189 Takao Ozawa v. United States, 260 U.S. 178 (1922).
} 
Caucasian and therefore belongs entirely outside the zone on the negative side."190 The Oregonian did not publish an editorial, perhaps finally satisfied with a federal solution, but commented in a news article that the ruling was expected to receive international attention, "notwithstanding the failure of the court to make any reference to its diplomatic significance." ${ }^{\prime 191}$ Indeed, Japan reacted negatively to the Court's decision. The New York Times reported that in Tokyo, the Hochi Shimbun newspaper stated, "If the Americans persist in their present attitude towards the Japanese, it is inevitable that racial strife will grow more pronounced." ${ }^{192}$

Recent historians have written much about the evolving definition of whiteness in U.S. law. Matthew Frye Jacobson argued that race was invented as a "powerful instrument for jealously guarding privilege rather than as a neutral, cooly biological basis for understanding the relationship amongst the world's peoples." ${ }^{193}$ Ian Haney Lopez analysis of the history of the legal construction of race points out that in the Ozawa ruling, the Court "ignored the implications of Ozawa's argument" that light skin qualified him as white. ${ }^{194}$ The fact that skin color does not align with racial taxonomies is now used as evidence that such racial divisions are socially constructed, but the Court in 1922 followed the scientists of the time who classified Japanese as Mongolian. The Court's ruling

\footnotetext{
190 U.S. v. Ozawa, 1922.

191 “Japanese Lose Citizenship Suit," Oregonian, November 14, 1922, 1.

192 "Tokio Press Still Angry," New York Times, November 18, 1922, 1.

193 Matthew Frye Jacobson, Whiteness of a DIfferent Color: European Immigrants and the Alchemy of Race (Cambridge: Harvard University Press, 1998), 234.

${ }^{194}$ Ian Haney Lopez, White By Law: The Legal Construction of Race (New York: New York University Press, 1996), 84.
} 
boosted the anti-Japanese movement by giving it scientific and legal backing, and would justify discrimination against the Japanese until the racial bar to naturalization was lifted in $1952 .{ }^{195}$

On the same day as the Ozawa decision, the Supreme Court also ruled against Takuji Yamashita. ${ }^{196}$ Yamashita had obtained citizenship twenty years earlier but had still been denied his license to practice law in 1902 by the Washington State Bar Association, who maintained that his citizenship was illegal. In 1920 he and Hyosaburo Kono petitioned the court for the right, as American citizens, to obtain corporation status for their real estate company. The U.S. Supreme Court ruled that, as in Ozawa's case, the men could not be legally naturalized citizens because they were not Caucasian. ${ }^{197}$

The next year the Supreme Court excluded East Indian immigrants from naturalization, using the opposite logic than employed in the Ozawa case. Bhagat Singh Thind was a Punjabi man from British India who had moved to the United States in 1913. After volunteering in the U.S. army during World War I, Thind moved to Oregon and applied for citizenship in 1920. Judge Charles Wolverton approved his naturalization papers, but the U.S. government challenged Thind's citizenship, likely due to his participation in the East Indian independence movement. ${ }^{198}$ Referring to the Ozawa ruling, Thind argued that as a northern East Indian he was an Aryan or Caucasian, but Justice Sutherland this time ruled that

\footnotetext{
${ }^{195}$ Ibid., 85.

${ }^{196}$ Yamashita v. Hinkle, 260 U.S. 199 (1922).

${ }^{197}$ Ichioka, The Issei, 225-226.

${ }^{198}$ Sucheng Chan, Asian Americans, 94.
} 
race classification was not enough for citizenship: color mattered. Thind was denied citizenship by the U.S. Supreme Court because of his brown skin and the ambiguity for Asian immigrants was settled: they would not be eligible for U.S. citizenship. ${ }^{199}$

\section{Closing of Immigration Doors}

The Ozawa decision culminated almost thirty years of Japanese challenges to vague U.S. naturalization law. In addition to cutting off the privileges of national citizenship, the ruling subjected Japanese immigrants to discriminatory state laws, such as the Oregon Alien Land Law, finally passed in $1923 .^{200}$ The Oregonian had by 1922 dropped its opposition to such a law, justifying the discrimination by noting that "Japan discriminates against particular nations just as we do, and for the same reason." ${ }^{201}$ The same editorial went on to bemoan the influx of Japanese from across the Mexican border as well as the American-born citizens who were becoming old enough to vote and would certainly demonstrate loyalty to Japan. This was a big change from earlier editorials, especially when expressing worry over "how to keep this a white man's country, especially as the fecundity of the white stock is failing." The Portland Chamber of Commerce, on the other hand, had continued to oppose the bill, maintaining that discrimination would harm business with Japan, and citing a Japanese company based in Seattle that moved to Portland in response to Washington's Alien Land Law. ${ }^{202}$ Public

\footnotetext{
${ }^{199}$ United States v. Bhagat Singh Thind, 261 U.S. 204 (1923)

${ }^{200}$ Johnson, “Anti-Japanese Legislation in Oregon,” 199.

201 “Japan's Own Medicine," Oregonian, June 23, 1922, 8.

202 Johnson, “Anti-Japanese Legislation in Oregon,” 199.
} 
opinion, like that of the Oregonian's editorial board, had turned more strongly against Japanese immigrants. As reflected in the 1922 election results, nativism ruled Oregon in the early 1920s and the Oregonian by 1923 no longer voiced opposition. The Oregon legislature also passed the Alien Business Restriction Act in 1923, sanctioning the municipal denial of business licenses to immigrants ineligible to citizenship and forcing such shop owners to advertise their nationality. ${ }^{203}$

Most damaging to U.S.-Japanese relations, however, was the use of the phrase "ineligible to citizenship" in the 1924 Immigration Act (also known as the Johnson-Reed Act) that justified the popular name of the law, the "Japanese Exclusion Act." ${ }^{204}$ The Oregonian covered the passage of the new law extensively, including publishing several editorials that year on the subject. In general, the editors supported the law and did not think Japan should be offended. ${ }^{205}$ A common theme was applause for Congress taking action to regulate Japanese immigration by law rather than diplomatic agreement. ${ }^{206}$ Overall, the Oregonian editors no longer sympathized with Japanese complaints. "The real grievance," the editorial stated, "is that (Japanese) people are placed in one general category with the very nations against which Japan itself discriminates and to which it claims superiority."

The Oregonian editors at first took offense with the Japanese

\footnotetext{
203 Azuma, “A History of Oregon's Issei, 1880-1952,” 339.

${ }^{204}$ Chuman, The Bamboo People, 103.

205 "Japan's Complaint Baseless," Oregonian, April 15, 1924, 12.

206 “The Only Possible Reply,” Oregonian, April 16, 1924, 12.
} 
ambassador's remarks that the act would produce "grave consequences." 207 A few days later, however, the same paper opined that Ambassador Hanihara's prediction was really referring to "harmed relations, not a threat of retaliation," and said that the Japanese were mortified and perplexed by the exclusion so steps should be taken "to demonstrate respect for the Japanese people in every way possible consistent with our policy." 208 The editorials also expressed a wish that Congress could have handled the issue with even greater sensitivity to Japanese perceptions. ${ }^{209}$ A further editorial said Japan had "cause to protest against the unceremonious manner in which the U.S. has settled for itself by domestic law the question of Asiatic immigration which this country has hitherto treated as a subject for diplomatic agreement." ${ }^{210}$ At the same time, however, the editors maintained that the United States had the right to do this and were not in violation of any treaties, and assured Japan that they did not "brand Japanese with the same inferiority as Japan puts on other Asiatic nations," but "only consider (the Japanese) so unchangeably different that we refuse to attempt assimilation of any of them." This denial of race hatred was a common theme in the Oregonian's support for anti-Japanese legislation.

Just after the passage of the Johnson-Reed Act, the Oregonian ran a column by a foreign correspondent in Japan that pointed out that the Japanese were offended because they "form the only yellow, brown, or black race that has

\footnotetext{
207 Ibid.

208 "No Real Cause of Offense," Oregonian, April 21, 1924, 8.

209 "Immigration and Exclusion," Oregonian, May 27, 1924, 8.

210 “Japan's Ground of Protest," Oregonian, June 3, 1924, 12.
} 
never bowed before some western race" and felt they had maintained their obligations under the Gentleman's Agreement. ${ }^{211}$ In general, the author said he encountered little hostility in Japan but that many he met were concerned about the rights of Japanese immigrants already living in the U.S.

Reactions in Japan to the new immigration law ran from mass demonstrations to calls for war to a suicide on the site of the former American embassy in Tokyo (destroyed by the 1923 fire). ${ }^{212}$ The dead man left a letter addressed to the American ambassador, stating his desire for the immigration act to be repealed, and his surprise that "the Americans, who advocate humanity, have disregarded the considerations of humanity by enacting this law." The Oregonian published the translation of this letter, which went on to say that "Japan has been humiliated by your country in the eyes of other nations without any reason we are able to understand," and "I would rather die than live to hate your country."213

The Oregonian continued to report on the tension caused by the act throughout 1924, including news of further suicides in California, rude treatment of American tourists in Japan, proposed boycotts by the Japanese press, and vandalism at the American embassy in Tokyo. ${ }^{214}$ The newspaper also sponsored a series of reports from former Reed College professor and president of the local Loyal Legion of Loggers and Lumbermen, Dr. Norman F. Coleman, on the

${ }^{211}$ Roderick Matheson, “Japanese Desire For Influx Denied,” Oregonian, April 15, 1924, 2.

212 "Hara Kari Committed," Oregonian, June 1, 1924, 1.

${ }^{213}$ Ibid.

214 "Strong Protest Framed by Japan," Oregonian, May 28, 1924, 1; “America Answer's Japanese Protest," Oregonian, June 17, 1924, 1; "Nippon Officials Offend Americans" Oregonian, June 25, 1924, 2; "Old Glory Is Cut Down," Oregonian, July 1, 1924, 1. 
reaction in Japan to the Exclusion Act. Coleman took a group of American students to visit Japan and submitted five pieces for publication about their journey. He and the students were impressed from the start of their visit, and he noticed that Japanese students were "as hearty and almost as noisy in the enjoyment (of sports) as Americans." ${ }^{215}$ Upon arrival in Yokohama, the Americans witnessed the destruction of the recent earthquake, which Coleman described as reminding him of Europe after the war. ${ }^{216}$ The Japanese they met expressed gratitude for American disaster relief, and only two men Coleman met in Yokohama ranted about the new immigration law (possibly because they had lived in the United States and were more accustomed to frankness, Coleman remarked). The group then travelled to the major cities of Honshu and were "at times embarrassed by the hospitality" of their hosts. ${ }^{217}$ Coleman was most impressed by the modern city of Osaka where he met people curious about U.S. industry. ${ }^{218}$ In his final travelogue, Coleman described Japanese reverence for American patriotic heroes and said he saw little outward resentment towards the U.S., even as the new immigration law went into effect. ${ }^{219}$ However, he also said the law was "like a blow from the clenched fist of a friend" and that many feared "unfortunately results from the weakened friendship of two great Pacific powers." Many Japanese keenly felt the sting after their country had struggled for

\footnotetext{
215 Norman Coleman, “Japanese Kindly To U.S. Students,” Oregonian, July 20, 1924, 2.

${ }^{216}$ Coleman, "Friendly Mission Cordially Received," Oregonian, July 23, 1924, 21.

${ }^{217}$ Coleman, "Japanese Shower Honors On U.S. Visitors," Oregonian, August 9, 1924, 11.

${ }^{218}$ Coleman, "Japanese Life Is Changing, But Holds Old Traditions," Oregonian, August 19, $1924,25$.

${ }^{219}$ Coleman, "Japanese Said To Revere Great American Patriots," Oregonian, August 21, 1924, 16.
} 
recognition as a world power itself. Coleman quoted one angry man he met who said America had "practically invited the 1,100,000,000 of colored people in the world to unite against the 500,000,000 white people," but assured readers that most thought this reaction extreme. The issue was serious, of course, because "it touches them where they are sensitive," Coleman said, but he believed that America could "continue to be a friend and teacher to this struggling people without throwing her doors wide to Oriental immigration." ${ }^{220}$ Coleman's assessment was similar to that of many previous Oregonian editorials which emphasized the importance of international relations but judged Japan's responses to be overreactions.

During the years from the passage of California's first Alien Land Act until the U.S. Immigration Act of 1924, the Oregonian opposed nativism at the state level while it waited for the federal government to settle the issue of Japanese naturalization. The need to not offend Japan, a WWI ally with a growing empire that could pose a threat, seemed to be the biggest concern. The Oregonian favored naturalization, with limits on immigration, and expressed disgust at the idea of intermarriage.

The anti-Japanese movement cooled off in Oregon and elsewhere after the 1924 Act went into effect. ${ }^{221}$ Many Japanese in Oregon left the state and likely returned to Japan. ${ }^{222}$ Those who remained focused on the futures of their American-born children. The citizenship of the Issei seemed a lost cause, but

\footnotetext{
${ }^{220}$ Ibid.

${ }^{221}$ Barbara Yasui, "The Nikkei in Oregon, 1834-1940,” 247.

${ }^{222}$ Azuma, “A History of Oregon's Issei, 1880-1952,” 339.
} 
many hoped that, over time, nativist sentiments would continue to relax and the Nisei could prove their ability to assimilate and exercise their well-deserved citizenship rights. This citizenship of the Nisei, however, would not protect them from being stripped of their rights if they lived on the West Coast after the bombing of Pearl Harbor. 


\section{Chapter 4: The Postwar Movement to Change Racial Requirements for Naturalization (1945-1952)}

Given the lack of protection their citizenship afforded West Coast Nisei who were relocated to concentration camps during the war, it is remarkable that citizenship was still so important to many Issei after $1945 .{ }^{223}$ In Oregon, the Japanese community was reduced after internment, but Issei and Nisei in the state did participate in the campaign to change U.S. naturalization law. The Oregonian editorial board came out in favor of such a change, but did not editorialize on the subject as much as it had in earlier decades, perhaps because there was not as much opposition to such a change and because other Cold War concerns took priority. The national context surrounding the issue of Japanese naturalization changed after 1945, with three main themes influencing public opinion. The Nisei's service in the war influenced public perceptions of Japanese Americans, and at the same time the creation of the United Nations and its Universal Declaration of Human Rights suggested to many that discrimination in naturalization law should change. The oncoming Cold War provided another context for the debate about naturalization, as the importance of fostering strong postwar alliances, especially with Japan, influenced U.S. lawmakers and the

${ }^{223}$ This study does not examine the period from 1924 to 1945, when the issue of Japanese immigration and naturalization was largely absent from the popular (non-Japanese) Oregon press. The incarceration of Japanese immigrants and natural-born Japanese American citizens is likewise not the focus of this paper, as it raises different legal questions. After the Supreme Court ruling against Japanese naturalization in 1922, the passage of discriminatory laws in Oregon (based on the language of the Supreme Court's ruling) in 1923, and the end of Asian immigration in 1924, the question of Japanese naturalization did not become a big issue again until the war ended and the non-citizenship of the Issei was presented in a new way. 
American public. That the law would finally change in 1952, the same year that the postwar occupation of Japan would end, suggests that creating good relations with Japan was a priority.

\section{Postwar Hints of Change}

Upon release from the incarceration camps, around 69 percent of the Japanese American families that had left Oregon returned. ${ }^{224}$ They faced opposition, notoriously so in the rural town of Hood River, in the Columbia River Gorge, but sentiments were also changing. In March, 1945, across the Columbia River from Washington State, an editorial in a Lewiston, Idaho newspaper decried the formation of the Oregon Property Owners' Protective League, which sought the passage of a constitutional amendment deporting all Japanese, including Nisei, because they complained that Japanese could not be good Americans. ${ }^{225}$ "It would be interesting to know the Oregon organization's definition of 'good American," the editors wrote, "(They do) not suggest that these Nisei have been guilty of a crime or that they have refused to contribute their share of blood and labor and money to the war, that they have not risked their own lives in the war against tyranny and barbarity, the war for a just peace for all peoples. No."226 The editorial went on to denounce discriminatory treatment of Japanese American citizens, comparing such behavior with Nazis or Japanese warlords, and to state that the efforts of the League were certainly not representative of the good people

${ }^{224}$ George Katagiri, "Japanese Americans in Oregon," The Oregon Encyclopedia, http://www.oregonencyclopedia.org/articles/japanese americans in oregon immigrants from th e west/\#.VjYwQ66rTeQ Accessed October 30, 2015.

225 "Hysteria in Oregon," Lewiston Morning Tribune, March 18, 1945.

${ }^{226}$ Ibid. 
of Oregon.

The themes cited in the editorial were typical of most postwar commentators, in Oregon and elsewhere, which usually drew attention to the service of Nisei who fought in armed forces. Whereas before the war, citizenship was not enough to prevent the mistreatment of the Nisei, and the courts had upheld the power of the federal government and state legislatures to deny rights to anyone of Japanese descent (Korematsu v. U.S., etc.), the postwar period brought some new respect to Japanese American citizens, largely due to the perceived loyalty demonstrated by military service and cooperation with wartime relocation. After the war, the hostility against the Japanese that had gone unchecked before was now tempered by some pro-Japanese support. Anti-Japanese sentiments still presented an obstacle but there were some friendly voices that had not spoken out before the war.

For example, alien land laws, which discriminated against both Issei and Nisei, began to succumb to challenges in the late 1940s. Anticipating the return of Japanese Americans and residents, the Oregon legislature enacted a new Alien Land Law in 1945, which strengthened the 1923 act of the same name and prohibited even the American-born children of the Issei from leasing land for their parents. Hoping to overturn the discriminatory statute, the newly reestablished Portland chapter of the Japanese American Citizens' League joined with local Issei and formed the Committee for Oregon Alien Land Law Test Case in April 
1946. ${ }^{227}$ The Multnomah Bar Association supported the effort, and in 1947, lawyers Verne Dusenbery and Allan Hart filed a suit for Kenji Namba, a Nisei, who wanted to lease land in Gresham for his father, Etsuo. ${ }^{228}$ The younger Namba had fought in the 442nd Regimental Combat Team during WWII. The Multnomah County Circuit Court ruled that while parts of the law were constitutional, the son did have the right to let his father work and live on his land. ${ }^{229}$ The plaintiffs sought to overturn the law in its entirety, and so appealed to a higher court. In 1949, the Oregon Supreme Court overturned the 1945 Alien Land Law. Justice George Rossman cited the 14th Amendment of the U.S. Constitution and opined that, "They are here lawfully and are entitled to remain." ${ }^{230}$ He applauded the efforts of Nisei soldiers and gave credit to their parents. He continued, "Our country cannot afford to create by legislation or judicial construction a ghetto for our ineligible aliens." Yet this is what the Oregon Alien Land Law essentially did, he said. ${ }^{231}$

Similar efforts were made in California. In 1948 the U.S. Supreme Court ruled that a California Alien Land Law denied an American citizen, Fred Oyama, his due process rights to own land, even if he wished to share that land with his non-citizen father. ${ }^{232}$ The Court did not go so far, however, as to wholly overturn the constitutionality of the act. Oregon's Supreme Court was the first to do this. California repealed its alien land law in 1956 and Washington State finally

227 Azuma, “A History of Oregon's Issei," 360.

228 "Alien Land Laws Face Court Test," The Oregonian, April 6, 1947, 1.

229 “Judge Declares Japanese May Live on Leased Land," The Oregonian, October 12, 1947, 18.

${ }^{230}$ Kenji Namba v. McCourt, 185 Ore. 579 (1949).

231 "State Court Voids Alien Land Law," The Oregonian, March 30, 1949, 1.

232 Chuman, The Bamboo People, 209-215; Oyama v. California, 332 U.S. 633 (1948). 
followed suit in $1966 .{ }^{233}$ Other state laws denying rights to "aliens ineligible for citizenship" were also challenged in the postwar period. California's statute denying fishing licenses to these aliens was struck down by the U.S. Supreme Court in $1948 .{ }^{234}$

While the defeat of discriminatory state laws was a step towards equality, the potential for discrimination against Japanese immigrants as "aliens ineligible for citizenship" remained so long as they were prohibited from becoming naturalized citizens. The Issei still wanted to become full members of the society they had lived in for decades. They still could not vote in the country that had sent their sons to war, and as most of them were in their fifties or older, the question of access to pensions troubled many.

\section{Campaign to Change Naturalization Laws}

The fact that "ineligibility for citizenship" denied the Issei so many rights motivated the postwar campaign to change U.S. naturalization laws. The need for such a change was acknowledged by non-Japanese friends of the Issei. For example, A.L. Wirin, an attorney with the American Civil Liberties Union, advocated naturalization for the Japanese when he testified at a 1945 House Committee on Immigration and Naturalization hearing. ${ }^{235}$ In 1946, the Japanese American Citizens' League made this a central campaign focus. ${ }^{236}$ Former Oregonian Minori Yasui, who had challenged the military curfew in March 1942

\footnotetext{
233 Robert Wilson and Bill Hosokawa, East To America: A History of the Japanese in the United States (New York: William Morrow and Company, 1980), 282.

${ }^{234}$ Takahashi v. Fish and Game Commission, 334 U.S. 410 (1948).

235 “12,000 Nisei Return West,” The Oregonian, August 29, 1945, 6.

236 “Japanese Coast Return 'Better Than Expected,"” The Oregonian, February 10, 1946, 14.
} 
and lost his case in the U.S. Supreme Court, was active with the Denver chapter of the JACL in 1946 and informed his counterparts in Portland that in Denver they were helping Issei file naturalization papers. ${ }^{237}$ "As you know, the citizenship issue is of considerable importance to Japanese Isseis," he wrote. "The question of deportation and the enforcement of anti-alien land laws are based upon the clause 'ineligible for citizenship.' Furthermore, as American citizens in a free democratic nation, it is my opinion that we cannot tolerate inconsistency in a nation dedicated to freedom and equality." He pointed out that only Japanese were affected by the exclusion law, since Chinese immigrants gained the right in 1943, and urged other JACL members to help the Issei. Many Issei did file declarations of their intent to naturalize, but were turned down as a matter of procedure. An example of the U.S. Department of Justice Immigration and Naturalization Service's response to such declarations is seen in a letter dated April 14, 1947, to George Mitsutaro Yoshihara, a resident of Seattle, who was told that aliens may file a declaration of intention but was reminded that "some races are not eligible for naturalization." ${ }^{238}$ Issei like Yoshihara must have known that such a response was likely, but perhaps believed that a strong show of interest would signal to immigration officials that they thought the time had come for change.

Richard J. Walsh, husband of novelist Pearl S. Buck, wrote a pamphlet

\footnotetext{
${ }^{237}$ Letter from Min Yasui to Mary Minamoto, September 25, 1946. PDX JACL Archives. ${ }^{238}$ Letter from H.E. Norwood, U.S. Department of Justice, Immigration and Naturalization Service, to George Mitsutaro Yoshihara, April 14, 1947. http://www.densho.org
} 
that was circulated by the JACL in 1947. "Now that Nazi Germany is gone, the United States is the only large country in the world that treats persons of certain "races" as unfit to become its citizens." Such exclusive discrimination against certain Asians, he said, was certainly useful to Communist propagandists, who could contrast racism in the United States with the Soviet Union, "where, as the Stalin Constitution provides, any advocacy of racial or national exclusiveness or hatred or contempt is punishable by law... How can the U.S. be so blind as to not see what all this means?"239 As the Cold War developed in the late 1940s and into the 1950s, this appeal to political consequences became commonly cited in the campaign to change naturalization and immigration laws. The three basic themes used to advocate for broader naturalization were the need to maintain good relations with Japan, the demonstrated loyalty of Japanese Americans during the war, and general appeals to equality and fairness.

In general, these reasons were by this time largely unopposed in the public arena. By the late 1940s, fewer people disputed that longtime Japanese aliens should be allowed to become American citizens. Other Asian immigrants had already been granted this privilege, beginning with the Chinese in 1943 and Filipinos and East Indians in 1946. ${ }^{240}$ Even Japanese aliens who had served in the U.S. military were finally allowed to become naturalized with the passage of the 1935 Nye-Lea Act. ${ }^{241}$ Dillon Myer, former head of the War Relocation

\footnotetext{
239 Richard J. Walsh, "For Equality in Naturalization," Summer 1947. PDX JACL Archives. 240 Roger Daniels, Guarding the Golden Door: American Immigration Policy and Immigrants Since 1882 (New York: Hill \& Wang, 2004), 93-95.

${ }^{241}$ Chuman, The Bamboo People, 166-167.
} 
Authority, believed that the lack of citizenship for the Issei deprived them of justice and recommended a new naturalization law. ${ }^{242}$ The 1947 Presidential Commission on Civil Rights deplored the discrimination against Japanese and Korean aliens:

"Although many of these people have lived in this country for many decades, will probably remain here until they die, have raised families of native-born American citizens, and are devoted to American principles, they are forbidden an opportunity to attain the citizenship status to which their children were born." 243

\section{Naturalization and Immigration}

Though there were few vocal opponents to changing naturalization law, the issue was more complicated because of the implications for immigration law. Based on their ineligibility for citizenship, Asians had been excluded from the national origins immigration quotas established by the 1924 Johnson-Reed Act. Now that Chinese, Filipinos, and East Indians, and likely soon Japanese, were eligible for citizenship, there was a need to re-examine the complicated system of U.S. immigration laws. White Americans who believed that long-time Japanese residents finally deserved American citizenship were less united in their ideas about Asian immigration. If the phrase "ineligible for citizenship" could no longer be used as the basis for excluding Asian immigrants, then how could Asian immigration be prevented, and should it?

Walsh, a member of the Committee for Equality in Naturalization,

\footnotetext{
${ }^{242}$ Dillon C. Myer, "WRA: A Story of Human Conservation," United States Department of the Interior, 1946.

${ }^{243}$ Report of the Presidential Commission on Civil Rights, November 2, 1947.
} 
acknowledged the connection between naturalization and immigration and tried to suggest a position that those favoring changes in naturalization law should take. "Immigration is admittedly a more controversial question than naturalization."244 He advocated the "sane" position of Earl G. Harrison, former Commissioner of Immigration and Naturalization, that immigrants should be permitted based on "personal qualifications" rather than country of birth. "(B)ecause of traditional objection to opening up immigration it may be necessary to move forward one step at a time. The first step obviously ought to be to permit the naturalization of those Asiatics who have so long lived among us."245

\section{Debate Over the Judd Bill}

The proposal to change U.S. naturalization law first reached the floor of the Congress when proposed by Minnesota Representative Walter Judd, a former missionary in China who had traveled in Japan. The Judd bill was debated by the 80th Congress at a hearing of the House Subcommittee on Immigration and Naturalization in April 1948. Judd began his testimony by addressing the need for comprehensive immigration reform. He firmly supported the principle of national origins quotas and wanted to maintain this principle, while also "extend[ing] the system to include certain peoples who heretofore have been

\footnotetext{
${ }^{244}$ Walsh, "For Equality in Naturalization," 1947. PDX JACL Archives.

245 The Committee for Equality in Naturalization included writer Pearl Buck, American Civil Liberties Union director Roger Baldwin, African American civil rights leader A. Philip Randolph, former Chief Justice Charles Evans Hughes, former Assistant Secretary of War and World Bank President John McCloy, former First Lady Eleanor Roosevelt, Mrs. Joseph Stilwell, theologian Rienhold Niebuhr, JACL leader Mike Masaoka, and Portland businessman and Reed College President E.B. MacNaughton.
} 
excluded because of their race." ${ }^{246}$ Citing the need to reduce a source of tension between the United States and other parts of the world affected by American immigration and naturalization policies, Judd said that his objective was, "on the one hand, to end discrimination in naturalization and immigration laws in a manner which conforms to the idea behind the national origins quotas, and on the other hand to grant immigration quotas to certain carefully defined areas in the Far East." 247 He called it "a matter of simple justice," and declared:

These people are here. They are legally here. They are entitled to stay here the rest of their lives. Their average age is above 50. From the standpoint of our own body politic it would be better to have them fully incorporated as citizens than as alien residents. They pay taxes. They are good law-abiding members of their communities. They have proved their conduct during the war, and especially through the conduct of their children who served with heroism, distinction, and valor in our armed forces, that they are loyal to the United States and fully worthy of American citizenship. ${ }^{248}$

Judd acknowledged that the second part of his bill was "more

complicated." He aimed to "eliminate racial discrimination in our immigration laws and still maintain our basic national origins quota principle." He stated that he wanted to prevent an "influx of people of Asian ancestry from non-quota countries such as Cuba or South American countries," therefore he would establish quotas based not on country of direct origin but on country of ancestry for Asians living in any part of the world. This would set up a different treatment

\footnotetext{
246 "Hearings Before the Subcommittee on Immigration and Naturalization of the Committee of the Judiciary of the House of Representatives: H.R. 5004 - to allow naturalization to all legal residents, make immigration quotas available to Asians, and other purposes." PDX JACL Archives.

${ }^{247}$ Ibid.

${ }^{248}$ Ibid.
} 
for Asians than any other persons, but Judd believed it would still "work to remove the stigma that at present attaches to complete prohibition of immigration from certain races," while still protecting against the "flooding of America with people of lower economic standards or other cultural patterns."249 Judd went on to say that his bill would have tremendous benefits in Japan, "where a fierce struggle is going on for the minds and hearts of the Japanese people," and, in contrast to the tyranny of the Soviet Union will show that the United States "believes in what it professes by bringing its actions in harmony with its words." ${ }^{250}$ As demonstrated here, Cold War politics had a huge impact on U.S. immigration and naturalization policy. Japanese exclusion was no longer tenable when the U.S. was trying to win the hearts and minds of potential Cold War allies. Judd cited support for removing racial barriers to naturalization from General Douglas MacArthur, head of the Supreme Command for Allied Forces in occupied Japan, representatives of the State and Justice Departments, and other members of Congress. Many of these testimonies referred to the benefits these changes in naturalization and immigration laws would have for foreign policy. Charles Bohlen, counselor for the Secretary of State, stated that such laws had "complicated the conduct of foreign relations for many years," and that discriminatory policies were "being used in foreign propaganda against the United

\footnotetext{
249 Ibid.
}

250 Ibid. 
States."251 Former Ambassador to Japan Joseph Grew testified that legal U.S. residents should be allowed and encouraged to become naturalized citizens and that "there can be no question whatsoever that the passage of the Immigration Act of 1924 undercut the position of liberal Japanese statesmen whose policy was based on friendship with America," thus giving extremists a "potent weapons with which to exacerbate Japanese-American relations" and greatly contributing to the recent war. ${ }^{252}$ Although he had not favored repeal of immigration exclusion laws at the time, Grew now believed this was the right thing to do.

The military service of Japanese Americans in WWII came up repeatedly at the hearings. Judd read letters from former Undersecretary of War John McCloy and General Mark Clark, who commanded Japanese American troops in Europe. Bertrand W. Gearhart, Representative from California, exemplified a change in sentiment from that state by endorsing naturalization rights and praising Japanese American military contributions.

The argument to lift the racial barrier to citizenship based on appeal to human rights was heard in the testimony of Dillon Myer, former head of WRA, who said that the most important reason to remove racial restrictions to naturalization was they had "been used by racist elements in various western states as the basis for discriminatory legislation which severely hampers thousands of people from making a living merely because their ancestor happens

${ }^{251}$ Letter from Charles E. Bohlen, Hearings from the Subcommittee on Immigration and Naturalization of the Committee of the Judiciary of the House of Representatives: H.R. 5004. PDX JACL Archives.

${ }^{252}$ Joseph Grew, Hearings from the Subcommittee on Immigration and Naturalization of the Committee of the Judiciary of the House of Representatives: H.R. 5004. PDX JACL Archives. 
to be Japanese..."253

Representing the national JACL, Mike Masaoka, veteran of the 442nd

Combat Unit of the U.S. Army, spoke of the need to grant citizenship to the parents of Japanese Americans, who taught them to love America so much that many would volunteer for military service. ${ }^{254}$ Masaoka extolled the most "essential” part of the Judd Bill, which would make citizenship possible to lawfully admitted aliens regardless of race. The great majority of those who would benefit from this bill, Masaoka acknowledged, were Japanese parents, "who entered this country thirty years ago for the same reasons that so many other immigrants came to our shores: to find new hope, new opportunities, and, above all, freedom. Mr Chairman," he explained, "I'm sure that you can understand our interest and our concern for this legislation. It's because this bill involves our parents, whom we admire and love.”255 Masaoka read statements from several Issei who gave their reasons for desiring citizenship. Mrs. Kin Tanahashi lost her son in the war, but hoped "that his death will help the public realize that we are Americans fighting for America, too. I have lived in this country for over thirty years," she said, "and it is my country just as it is was (my son's), and I feel the

253 Dillon Myer, Hearings from the Subcommittee on Immigration and Naturalization of the Committee of the Judiciary of the House of Representatives: H.R. 5004. PDX JACL Archives. ${ }^{254}$ Masaoka was a controversial figure in the Japanese American community for his role urging the Nisei to fight for the United States during the war. He questioned the loyalty of those who opposed the West Coast removal or who did not want to serve in the U.S. military, and in doing so displaced Issei leaders as a spokesperson for Japanese American interests. For more, see Paul Spickard, "The Nisei Assume Power: The Japanese Citizens League, 1941-1942," Pacific Historical Review, 52, (May, 1983), 147-174.

${ }^{255}$ Mike Masaoka, Hearings from the Subcommittee on Immigration and Naturalization of the Committee of the Judiciary of the House of Representatives: H.R. 5004. PDX JACL Archives. 
way he felt - that of any American loving his country."256 Yosuke Nakano wrote that he worried about the stigma having alien parents caused his two daughters, calling it "a shadow over the family which I wish to remove." ${ }^{257}$ Fred Nitta, who had served as a translator for the OSS during the war, wrote, "I will be one of the most happy persons in the world when I will be allowed to become an American citizen, because ever since I came to this country at the age of 14 , to become a citizen of this great country has been my ambition." 258 Masaoka said that the Nisei suffered, too, because "we are second-class citizens" and the alien status of their parents "is often used as the basis of discriminatory treatment" because "since our parents cannot become citizens, our own citizenship must be tainted." 259 Masaoka only addressed the naturalization portion of the bill, which suggests that this change was of such great importance that the continued discrimination against new immigrants was a price worth paying.

Only two statements were presented at the Judd hearings opposing the proposed bill. One came from Harry Hayden, Jr. of the American Legion, who feared competition for jobs, and the other from a group called the American Coalition, which quoted FDR's fear of racial miscegenation and contended that

\footnotetext{
${ }^{256}$ Letter from Mrs. Kin Tanahashi, Hearings from the Subcommittee on Immigration and Naturalization of the Committee of the Judiciary of the House of Representatives: H.R. 5004. PDX JACL Archives.

${ }^{257}$ Letter from Yosuke Nakano, Hearings from the Subcommittee on Immigration and Naturalization of the Committee of the Judiciary of the House of Representatives: H.R. 5004. PDX JACL Archives.

${ }^{258}$ Letter from Fred Nitta, Hearings from the Subcommittee on Immigration and Naturalization of the Committee of the Judiciary of the House of Representatives: H.R. 5004. PDX JACL Archives. ${ }^{259}$ Masaoka, Hearings from the Subcommittee on Immigration and Naturalization of the Committee of the Judiciary of the House of Representatives: H.R. 5004. PDX JACL Archives.
} 
the Asian races were too different to be assimilated. ${ }^{260}$

\section{Oregonians React to the Judd Bill}

Oregon lawyer Verne Dusenbery, who was arguing the Namba case at the time, wrote a letter to The Oregonian urging support of the Judd bill. "The Judd bill will pass practically without opposition if the people of the Pacific coast let congress know they favor it," wrote Dusenbery. ${ }^{261}$ He cited support from the Los Angeles County Board of Supervisors and other California political groups and said he felt "certain that the people of Oregon will not lag behind California in advocating belated justice for this small group of deserving people."

The Portland chapter of the JACL had recently regrouped and, following directives from the national leadership, was committed to lobbying for Issei citizenship. The organization had some difficulties recruiting a large membership (perhaps because many Nisei were more focused on their own problems, such as fighting against more subtle forms of housing discrimination), but a core group was active in the early postwar period. ${ }^{262}$ Mary Minamoto, who served as the chapter's secretary and then president, wrote to members of Oregon's congressional delegation, urging them to drop racial barriers to naturalization. She thanked Representative Homer Angell for his efforts towards passage of the evacuation claims bill, expressed her interest in the passage of the equality in

\footnotetext{
${ }^{260}$ Hearings from the Subcommittee on Immigration and Naturalization of the Committee of the Judiciary of the House of Representatives: H.R. 5004. PDX JACL Archives.

261 Verne Dusenbery, “Japanese Bill,” The Oregonian, April 25, 1948.

${ }^{262}$ Robert Hegwood, "Erasing the Space Between Japanese and American: Progressivism, Nationalism, and Japanese American Resettlement in Portland, Oregon, 1945-1948," Thesis, January 1, 2011, https://dr.archives.pdx.edu/xmlui/handle/psu/7070.
} 
naturalization bill, and asked for advice on how to support it. ${ }^{263}$ Angell wrote back that he would consider the legislation and that she should write to Representative Judd himself. ${ }^{264}$

\section{Judd Bill Delayed}

As debate over the merits of the Judd Bill continued into 1949, the Oregonian covered the issue and editorialized in support of its passage. "Not the least of our national errors has been the raising of racial barriers in immigration and naturalization laws - barriers based on prejudice and senseless fears and serving no useful purpose." 265 This marked the first time the Oregonian editorial board advocated for Japanese citizenship since the early 1920s, calling the discrimination a basic injustice against minorities. "The strongest arguments for (Issei) citizenship," the editorial continued, "come from their American-born sons and daughters - some of them veterans of the American armed forces - who wish them to be given, before it is too late, the full privileges of residence in the country of their choice." The Oregonian cited State Department support for the bill, as it would improve foreign relations "at a time when Red propagandists are seeking to inflame the Orient against this nation." In six months the Communists would win the civil war in China and throughout the American occupation of Japan there was a strong desire to prevent a similar conflict there.

Mary Minamoto continued to write to Congress during its 81 st session. By this time Senator Pat McCarran, a Republican from Nevada and chair of the

\footnotetext{
${ }^{263}$ Letter from Mary Minamoto to Rep. Homer Angell, November 4, 1948. PDX JACL Archives. ${ }^{264}$ Letter from Homer Angell to Mary Minamoto, November 16, 1948. PDX JACL Archives. 265 "Return to First Principles," The Oregonian, April 12, 1949, 16.
} 
Senate Judiciary Committee, was promoting the issue. Minamoto urged him to give his full attention to the Judd Bill, enclosing a letter she wrote to President Truman. ${ }^{266}$ She also wrote to Oregon Senator Wayne Morse to solicit his help in making the issue a priority. ${ }^{267}$ In his reply, Senator Morse expressed pessimism that the bill would come before the full Senate in that session. ${ }^{268}$ Oregon Senator Guy Cordon also responded to Minamoto that he had spoken of the matter to McCarran but no action was yet scheduled. ${ }^{269}$

The Judd bill passed the House for the third time in June, 1949, but remained stalled in the Senate judiciary committee. ${ }^{270}$ The Senate finally joined the House in passing the measure the following year and a joint bill was drafted. ${ }^{271}$ When the Oregonian covered the legislation, the immigration quotas were not mentioned, but rather the bill was presented as only dealing with naturalization. ${ }^{272}$ When President Truman vetoed the bill in September 1950, the national Anti-Discrimination Committee of the JACL called on Portland and other chapters to wire their congressional delegations to urge an override. ${ }^{273}$ The override campaign failed, however, and Japanese Americans who hoped their parents could soon qualify for U.S. citizenship would have to continue their fight in the 82nd Congress.

266 Letter from Mary Minamoto to Senator Pat McCarran. PDX JACL Archives.

${ }^{267}$ Letter from Mary Minamoto to Senator Wayne Morse. PDX JACL Archives.

${ }^{268}$ Letter from Senator Wayne Morse to Mary Minamoto. PDX JACL Archives.

${ }^{269}$ Letter from Senator Guy Cordon to Mary Minamoto. PDX JACL Archives.

270 "House votes aid to Asians," Oregonian, June 7, 1949, 6.

271 "Naturalizing Act Awaiting Action," Oregonian, July 27, 1950, 6.

272 "Naturalization Bars Lifted for Asiatics," Oregonian, August 15, 1950, 6.

273 Telegram from Joe Grant Masaoka to Mary Minamoto, 9/12/50. PDX JACL Archives. 
At the end of 1950, the San Francisco Nichi Bei Times ran an op-ed praising Congressman Judd for his efforts to help win naturalization rights for the Japanese. He can "pronounce the name Mike Masaoka with the same I-knowwho-I'm-talking about sureness, clarity, and fluency that he dedicates to such names as Bunche, Baruch or Acheson...," Peter Ohtaki wrote, and even before Judd entered public service, he was "aware that racial discrimination, besides being morally wrong, contains the seeds of international unrest and war.",274

As was expected, the House again approved the bill in 1951, responding to language issues Truman cited in his veto. ${ }^{275}$ The Senate passed a similar bill the next winter ${ }^{276}$ and the joint McCarran-Walter Act again went to both houses. Mary Minamoto corresponded with Representative Walter Norblad, who wrote that he would keep her views in favor of the legislation in mind when the joint bill came to vote. $^{277}$

\section{Opposition to National Origins Quotas}

By now the opposition had more time to formulate an alternative bill.

Senator Herbert Lehman (D-NY) sponsored legislation that would widen immigration policies. He rejected the McCarran bill as too restrictive, saying that it would "establish new forms of racial discrimination, weaken civil liberties, and establish 'police state principles and methods for dealing with immigrants and

\footnotetext{
274 “Walter Judd: Mr. Justice,” Nichi Bei Times, December 24, 1950.

275 "House Okeys Bill to Aid Orientals," Oregonian, February 20, 1951, 4.

276 "Plan Favors Entry Quota," Oregonian, January 29, 1952, 4.

277 Letter from Walter Norblad to Mary Minamoto, 3/11/52. PDX JACL Archives.
} 
aliens." "278 The New York Times editorial board favored Lehman's bill, which was co-sponsored by Minnesota senator Hubert Humphrey, opining that American immigration policy needed an overhaul, but that the McCarran bill was worse than the status quo. ${ }^{279}$ "We seriously doubt," the editorial stated, that most Americans support the "racist, illiberal philosophy" that the McCarran-Walter bills relied on. While the McCarran bill "does make a valuable gesture toward removing racial discrimination by granting nominal quotas to Asiatics... it continues and extends the vicious principle of determining nationality of halfAsiatics on the basis of race instead of on the normal basis of country of birth." 280 Prominent African American leaders also opposed the McCarran bill, which decreased the quota for Caribbean immigrants. Representative Adam Powell said the bill discriminated against Negroes. ${ }^{281}$

Although the JACL staked out a national position in favor of the bill, not all Japanese Americans agreed. Samuel Ichiye Hayakawa, a professor in Chicago, denounced the JACL for supporting the bill, writing in the Chicago Shimpo newspaper that, "to secure the rights to naturalization of Issei at the cost of all the questionable and illiberal features of the McCarran-Walter Bill appears to be an act of unpardonable shortsightedness or cynical opportunism." 282 Hayakawa deplored the bill for giving the government the power to deport aliens suspected of subversive activities and even strip citizenship from suspected

\footnotetext{
278 “Lehman Criticizes Immigration Bill," New York Times, April 6, 1952, 60.

279 “The Anti-Immigration Bill," New York Times, May 14, 1952, 26.

280 Ibid.

281 “House Vote Would Lift Alien Bar," Oregonian, April 26, 1952, 1.

282 Greg Robinson, After Camp: Portraits in Midcentury Japanese American Life and Politics (Berkeley: University of California Press, 2012), 97-98.
} 
Communists. Hayakawa himself was not willing to take naturalization rights (he was a Japanese Canadian) at such a cost. ${ }^{283}$ Journalist Togo Tanaka similarly denounced the McCarran-Walter Act. ${ }^{284}$

\section{Truman Weighs the Bill}

The McCarran-Walter Omnibus Immigration and Nationality Act passed the House on April 26 and the Senate on June 12. ${ }^{285}$ As Truman had previously vetoed such legislation, it was not clear whether the latest version would win his approval. The Eugene Register-Guard ran a column by national journalist Marquis Childs that analyzed the votes on the bill. ${ }^{286}$ In the Senate, the bill had passed thanks to a coalition of Republicans and southern Democrats. A few Republicans (including Senator Wayne Morse of Oregon) and most northern Democrats were against the measure, perhaps favoring the Lehman-Humphrey bill instead. The low quotas for eastern Europeans and Asians were worrisome to many Democrats because they relied on the support of these ethnic populations. Childs acknowledged that Truman favored the part of the bill that would allow Asians to become naturalized citizens, but would probably veto the bill because it discriminated against eastern Europeans. However, Childs warned, a veto would hurt the State Department, although officials from that department favored passage of the bill, because Senator McCarran chaired the Appropriations Subcommittee that controlled the department's budget and might hold the

\footnotetext{
${ }^{283}$ Ibid.

${ }^{284}$ Ibid.

285 "Immigration Bill Approved," Oregonian, June 12, 1952, 6.

286 "Demos Worried Over Quota Bill," The Eugene Register-Guard, June 17, 1952.
} 
President's veto against it. ${ }^{287}$

After some delay, Truman did veto the bill. ${ }^{288}$ In a speech explaining his veto, Truman spoke of the "difficult problem of weighting the good against the bad." 289 He called the bill a "step backward" and regretted that he could not approve it. Although it removed racial bars to naturalization, "now this most desirable provision" comes with others "which would perpetuate injustices of long standing against many other nations of the world, hamper the efforts we are making to rally the men of East and West alike to the cause of freedom, and intensify the repressive and inhumane aspects of our immigration procedures."290 The price that many Japanese Americans were willing to pay for Issei naturalization was, for Truman, "too high." Although he could agree with "the idea of quotas in general," he found the quotas provided in the bill to be insufficient and "insulting to large numbers of our finest citizens, irritating to our Allies abroad, and foreign to our purposes and ideals." ${ }^{291}$ He especially deplored how the bill would keep out immigrants from eastern Europe who may be fleeing communist governments, and also acknowledged that the quotas discriminated against Asians. He recommended a bill solely focused on removing racial barriers to citizenship, and more time to develop a fairer immigration bill.

\section{Response to Truman's Veto}

The JACL stepped up its efforts and urged Congress to override the veto.

\footnotetext{
287 Ibid.

288 "President Vetoes Immigration Bill as Discriminatory," The New York Times, June 26, 1952, 1.

289 “Text of Truman's veto speech,” New York Times, June 26, 1952, 14.

290 Ibid.

291 Ibid.
} 
In a report to the JACL Biennial Convention, held during the week of the veto in San Francisco, Mike Masaoka wrote that the liberal substitute to the McCarran bill, the Lehman bill, was clearly unsatisfactory to the majority of the Senate and especially the House. ${ }^{292}$ This acknowledgement reveals that while a more liberal bill may have been ideal for the Japanese American community, it was unlikely to pass and thus the current bill was the best they could hope for. The House, followed by the Senate, did what they had failed to do in 1950 and overrode President Truman's veto on June $27 .{ }^{293}$ Oregon senator Wayne Morse was among 26 senators, mostly Democrats, who voted not to override, while Oregon's other senator, Guy Cordon, joined the majority and defeated the veto. ${ }^{294}$ Mary Minamoto described the reaction at San Francisco JACL conference in a letter to Rep. Norblad: "the opening ceremony was interrupted on June 26 with the announcement of the House's action" and the next morning the session was broken up "with the good news of the Senate's action overriding the president's veto." ${ }^{295}$ According to Minamoto, the room was full of the tears of both the Nisei members of the JACL and their Issei parents who were observing the session.

"Those in charge had much difficulty conducting the meeting as previously scheduled," she wrote, thanking the congressman for remembering her interest in the law and sending her an official copy. ${ }^{296}$

\footnotetext{
${ }^{292}$ Mike Masaoka, JACL-ADC Biennial Report for the 12th Biennial National JACL Convention, San Francisco, June 25-30, 1952. PDX JACL Archive.

293 "House Overrides Veto By Truman," Oregonian, June 27, 1952, 1.

294 "Senate Roll-Call," New York Times, June 28, 1952, 10.

${ }^{295}$ Letter from Mary Minamoto to Walter Norblad. PDX JACL Archives.

${ }^{296}$ Ibid.
} 
The bill was generally regarded as an achievement by Japanese Americans, although it had serious flaws and did not satisfy all. The JACL-led campaign, including members in Portland, sacrificed the issue of discriminatory quotas in order to ensure citizenship privileges for the Issei. The New York Times editorial board denounced the new law for shutting out those who "most need a refuge against Communist tyranny," though it also acknowledged the "virtue" of naturalized citizenship and "token quotas from the free Asiatic nations."297

Although the Oregonian gave front page coverage to the House's override of the veto, the paper did not editorialize on the topic at any point that June. This seems strange, given the amount of editorials on the topic in the past; however, it is likely that, as so few Oregonians were directly affected by the new legislation, the editorial board chose to devote its front and opinion pages to the issues that concerned more of its readers at the time: presidential election politics and ongoing coverage of the Korean War.

By 1952, the opposition to Japanese naturalization in Oregon and elsewhere in the United States had greatly diminished, as the heroism of Japanese American soldiers in the war, the stronger focus on human rights in the era of the new United Nations, and Cold War politics had made offering citizenship to Japanese immigrants an obvious conclusion for many. The issue of restrictive immigration quotas was more contentious, and most supporters of Japanese naturalization were willing to accept the quotas for the time-being.

297 “Victory for a Bad Bill,” New York Times, June 28, 1952, 18. 


\section{Chapter 5: Effects of the McCarran-Walter Act in Oregon (1952)}

\section{A New Era for the Issei}

The change in U.S. naturalization law meant that the Issei and other Asians who had been barred from naturalization previously could now become U.S. citizens. Quotas given to previously excluded Asian countries meant that a limited number of Asian immigrants could now enter the United States. Japanese and Koreans were the two groups that were most affected by the law, as other Asians had been directly allowed to naturalize by previous legislation. This brief chapter examines the impact of the legislation in Oregon and the continued efforts in the immediate aftermath to address the discriminatory immigration quotas.

The McCarran-Walter Act went into effect on December 25, 1952. In anticipation of the new law, Portland Issei became more involved in electoral politics, even when they could not vote in the November election. ${ }^{298}$ Issei who visited a campaign rally for Robert Thornton, a former missionary and the Democratic candidate for Oregon's attorney generalship, were pleased to hear him briefly address the crowd in Japanese. ${ }^{299}$ The day after the Act went into effect, the Oregonian reported a lack of a rush for applicants. ${ }^{300}$ The first Japanese immigrants to be naturalized under the Act took the oath of citizenship in Los Angeles, alongside inductees from 33 other countries, including the Czech

\footnotetext{
${ }^{298}$ Letter from Mary Minamoto to Robert Thornton, Oregon Attorney General candidate, October 9, 1952. PDX JACL Archives.

${ }^{299}$ Letter from Mary Minamoto to Robert Thornton, October 29, 1952. PDX JACL Archive.

300 “Citizenship Lure Slight,” Oregonian, December 26, 1952, 11.
} 
movie star Hedy Lamarr. ${ }^{301}$ (Lamarr got the mention in the Oregonian's headline, the Japanese did not.) Meanwhile, the first Issei in Portland were preparing for their citizenship exam, another requirement of the new law, in the winter of $1953 .^{302}$

Throughout the rest of 1953 and 1954, the Oregonian continued to update readers on the steady flow of newly naturalized Japanese American citizens. ${ }^{303}$ Oregonian Associate Editor Malcolm Bauer gave an address to a group of newly inducted American citizens in July, 1954, in which he told them, "in America there is bigotry and prejudice and injustice and demagoguery. All these I would call un-American... but there can always be hope that such things will not exist- or at least exist at the very minimum. Even more important," he added, "in America there can be freedom of action to see that they do not exist." 304 Japanese Americans present at the address might have felt that point directly reflected their own experience. A Korean man at the ceremony commented, "Why did I wait 38 years before applying for citizenship? Well, you ought to know the answer as well as I."305

\section{The legacy of the McCarran-Walter Act}

In a 1955 tribute to the JACL on its 25 th anniversary, Walter Judd said the

\footnotetext{
301 “Actress Hedy Lamar Gets US Citizenship,” Oregonian, April 11, 1953, 11.

302 “42 Japanese Prepare for Citizenship,” Oregonian, April 27, 1953, 14; “Japanese Take First Step Along Citizenship Route” Oregonian, May 29, 1953, 5.

303 "Youngest Citizen Sworn In at Court Ceremony, Along with Natives of 22 Foreign Countries ," Oregonian, September 10, 1953, 12; "Ex-Aliens Become US Citizens in District Courthouse Ceremony", Oregonian, July 2, 1954, 21.

304 “Ex-Aliens Become US Citizens in District Courthouse Ceremony”, Oregonian, July 2, 1954, 21. 305 Ibid.
} 
naturalization and immigration bill would not have passed without the efforts of the organization. ${ }^{306}$ In Oregon and elsewhere, Issei continued to file for citizenship. ${ }^{307}$ At the same time, the Commission on Immigration and Naturalization, which Truman had created immediately after the Act was passed, held hearings on the merits and deficits of the McCarran-Walter Act. According to Elliott Barkan, the significance of the changes to naturalization law was overshadowed by the need to reform the immigration quotas and thus has been overlooked by many historians. ${ }^{308}$

In December 1955, Mike Masaoka testified for the JACL, submitting a statement that declared, "JACL then believed that the liberalization proposed, especially insofar as persons of Japanese ancestry in particular and Asians generally were concerned, were considerable and justified the evaluation that, weighed in the balance, the 'good features outweighed the bad.",309 For many years, due to the "invidious hands of the racemongers in the hostile west," the "ineligibility to citizenship" clause was used as "an effective weapon to curb his economic and social development." 310 Masaoka explained that the compromised bill was the best possible outcome at the time, and that "by far the most important feature of the new law is the complete repeal of all racial qualifications for

\footnotetext{
306 "Tribute to the JACL on its 25th Anniversary," Congressional Record. PDX JACL Archive. 307 "120 Citizens Greeted in Naturalization Program: Judge East Urges Exercise of Right to Cast Ballot," Oregonian, September 6, 1956, 38.

${ }^{308}$ Barkan, From All Points, 448.

${ }^{309}$ Mike Masaoka, Statement to the Commission on Immigration and Naturalization, December 1, 1955, 1. PDX JACL Archive. 310 Ibid.
} 
naturalization."311 Estimating that 20,000 Issei had become citizens in the three years since the law went into effect, Masaoka called the story of the new elderly Japanese Americans a "thrilling epic of patience, fortitude, faith and vision seldom, if ever, surpassed in our history." 312 While praising the change, Masaoka added that history may have been much different had Japanese immigrants been allowed to naturalize as other aliens could from the beginning, theorizing that the mass evacuation and even the war itself might have been avoided. ${ }^{313}$

Despite the merits of the naturalization statutes, Masaoka also testified that the act was not perfect, and recommended some changes to the commission. ${ }^{314}$ He hoped that Asians could be treated the same as Europeans in terms of immigration policy. The United States "can ill afford to neglect or fail to consider the hopes and aspirations of the Asian and Pacific peoples," he declared, prophesying that "the next era of civilization will develop around the Pacific basin, that challenging areas where three-fifths of the world's population resides with its tremendous potential for trade and commerce and peace with honor in our time."315 Masaoka urged the repeal of the national origins quotas and admitted a desire to increase the number of immigrants from Japan and Asia. He worried that revisions thus far proposed to eliminate national origins but maintain a unified quota system would likely continue to discriminate against Asians. ${ }^{316}$ Ultimately, Masaoka hoped the commission would find a way to increase the

${ }^{311}$ Ibid., 5 .

${ }^{312}$ Ibid., 6.

${ }^{313}$ Ibid., 7.

${ }^{314}$ Ibid., 9 .

${ }^{315}$ Ibid., 10.

${ }^{316}$ Ibid., 12. 
number of immigrants from Japan and Asia that would be allowed to come to the United States and become Americans, but stood by his decision to support the Act as it was passed in 1952.

While campaigning for the presidency in 1960, John F. Kennedy met with a group of Japanese Americans and denounced the McCarran-Walter Act for its discriminatory anti-Asian quotas. ${ }^{317}$ This signaled commitment to change immigration laws must have pleased many, but by failing to recognize the extent to which Japanese Americans cherished the act for its naturalization provisions, historian Roger Daniels points out, Kennedy demonstrated a "lack of sensitivity" to Asian American issues. The shortcomings of the act did not erase the widelyheld view that it was a major achievement that improved the lives of the Issei.

After over a decade of gathering testimonies regarding the effects of the 1952 Immigration Act, the Commission on Immigration and Naturalization made recommendations to change the U.S. immigration quota system. President Kennedy supported these changes and Congress enacted a new immigration act in 1965 that abolished the national quotas and moved to larger hemispheric quotas instead, opening the United States to increased immigration. ${ }^{318}$

\footnotetext{
${ }^{317}$ Roger Daniels, "United States Policy Towards Asian Immigrants: Contemporary Developments in Historical Perspective," International Journal 48 (1993), 323.

${ }^{318}$ Edward M. Kennedy, "The Immigration Act of 1965," The Annals of the American Academy of Political and Social Science 367, (Sep., 1966), 137.
} 


\section{Chapter 6: Conclusion}

Many Americans today are surprised to learn that U.S. laws prevented Asian immigrants from becoming naturalized citizens until 1952, thus the story of Japanese Americans and their non-Japanese allies campaigning for the right to citizenship to be free from racial barriers is especially important to tell. The Oregonian newspaper, one of the oldest and most widely read newspapers on the West Coast, was at first ambivalent towards Asian naturalization, then appealed to federal authority on the matter, criticizing California and other states that used a non-federally sanctioned interpretation to discriminate against Japanese and thus risk provoking war with Japan, then dropped the issue once the federal judicial and legislative branches had ruled against Asian naturalization and immigration, and then after the war advocated in favor of allowing Asians to become American citizens. Throughout the Oregonian's treatment of the subject, several themes emerged.

The threat of war with the empire of Japan was especially alarming to Oregonian editors. When California tried in 1909 and succeeded in 1913 in enacting an alien land law that discriminated against Japanese land ownership on the basis of "ineligibility to citizenship," Oregonian editorials warned that Japan would take offense and California should not provoke an international crisis. When the U.S. and Japan were allies during WWI, the Oregonian was especially influenced by the pro-Japanese message spread by Japanese spokesperson K.K. 
Kawakami and missionary Sidney Gulick, who both argued that granting citizenship to existing Japanese residents in the U.S. would create peace between the two countries. The Oregonian staff wrote many editorials in favor of Japanese naturalization and later, in the early 1920s, when the anti-Japanese movement grew in Oregon and pushed for an alien land law such as that in California, the editors opposed the measure.

The appeal to federalism was also apparent in Oregonian editorials from the 1906 San Francisco school segregation controversy until the federal government settled the matter in 1922. California's actions were criticized as being beyond the scope of state authority. Because of the foreign policy implications, the Oregonian deferred to federal authority to decide who was eligible for naturalization and thus subject to discriminatory alien land laws. It rejected such laws when they came up in Oregon in the early 1920s, but dropped its opposition once the U.S. Supreme Court ruled that Asians were not eligible to naturalize. This shows that the appeal to federal authority was more influential on Oregonian editors than wishes not to offend Japan or Japanese Americans. As long as Japan was to be offended, the Oregonian wanted the U.S. government to take responsibility.

The legal definition of whiteness was the basis for discriminatory laws aimed at Japanese immigrants. The Oregonian avoided this issue by appealing to federal authority to decide the matter and emphasizing foreign policy priorities. From the beginning of the century through the 1920s, however, the Oregonian 
expressed fear of miscegenation, creating an awkward duality between respect for the nation of Japan (so as not to provoke war with her) while also viewing Japanese people as being quite different from white Americans. The Oregonian did not comment on whether Takao Ozawa's command of the English language or Christian faith made him "white" or not, but accepted the Supreme Court's judgment that he did not meet the legal definition of a "free white person" that the 1791 Naturalization Act required.

Nativism inspired the exclusion movements in California and Oregon. In the 1920s, Oregon had an active Ku Klux Klan which lobbied lawmakers to keep Oregon free of Catholics, Jews, Asians, and other immigrants. Oregonian editors urged nativists to curb their hostility towards immigrants, while agreeing that limitations were necessary. The Oregonian opposed Oregon's Alien Land Act when it was proposed, and criticized those who decried a Japanese invasion. In general, the Oregonian did not see Japanese immigration or naturalization as a huge threat to the state, but did fret over mixed marriages.

In the years following World War II, when the Issei were the largest Asian group U.S. laws still prohibited from naturalization (Chinese, Indians, and Filipinos having been granted the right during or just after the war), Japanese Americans in the JACL and their non-Japanese allies campaigned for the racial bar to be lifted. The Oregonian expressed support for the campaign in 1949, but did not editorialize on the subject any further. The loyalty of Japanese Americans during the war, focus on human rights as promoted by the new United Nations, 
and the need for Cold War allies demanded a change in U.S. naturalization and immigration policy. Japanese Americans were for the most part willing to accept limited immigration in return for full naturalization rights, and the Oregonian did not comment. Other Cold War concerns may have taken priority for the editors and for the Oregonian public in general, such as the Korean War, McCarthyism, and the nuclear arms race. 


\section{Bibliography}

Ancheta, Angelo N., Race, Rights, and the Asian American Experience. New Brunswick, New Jersey: Rutgers University Press, 1998.

Azuma, Eiichiro. “A History of Oregon's Issei, 1880-1952.” Oregon Historical Quarterly 94 (Winter, 1993/1994), 315-367.

Azuma, Eiichiro. "Dancing with the Rising Sun: Strategic Alliances between Japanese Immigrants and their 'Home' Government." In The Transnational Politics of Asian Americans, edited by Christian Collet and Pei-Te Lien, 25-37. Philadelphia: Temple University Press, 2009.

Azuma, Eiichiro. "The Politics of Transnational History Making: Japanese Immigrants on the Western 'Frontier,' 1927-1941." The Journal of American History 89 (2003): 1401-1430.

Azuma, Eiichiro. Between Two Empires: Race, History, and Transnationalism in Japanese America. New York: Oxford University Press, 2005.

Barkan, Elliott Robert. From All Points: America's Immigrant West, 1870 s-1952. Indiana: Indiana University Press, 2007.

Buell, Raymond Leslie. "The Development of the Anti-Japanese Agitation in the United States.” Political Science Quarterly 37 (1922): 605-638.

Buell, Raymond Leslie. "The Development of the Anti-Japanese Agitation in the United States.” Political Science Quarterly 38 (1923): 57-81.

Chan, Sucheng. Asian Americans: An Interpretive History. New York: Twayne Publishers, 1991.

Chin, Gabriel J. "Twenty Years on Trial: Takuji Yamashita's Struggle for Citizenship." In Race on Trial: Law and Justice in American History, edited by Annette Gordon-Reed, 103-117. New York: Oxford University Press, 2002.

Chuman, Frank. The Bamboo People: The Law and Japanese Americans. Del Mar, California: Publisher's Inc., 1976.

Consulate-General of Japan, compiler. Documental History of Law Cases Affecting Japanese in the United States, 1916-1924. San Francisco: Arno Press, 1978.

Daniels, Roger. Asian America: Chinese and Japanese in the United States since 1850. Seattle: University of Washington Press, 1988.

Daniels, Roger. Guarding the Golden Door: American Immigration Policy and Immigrants Since 1882. New York: Hill \& Wang, 2004.

Daniels, Roger. The Politics of Prejudice: The Anti-Japanese Movement in California and the Struggle for Japanese Exclusion. Berkeley: University of California Press, 1999.

Daniels, Roger. "United States Policy Towards Asian Immigrants: Contemporary Developments in Historical Perspective," International Journal, 48 (1993): 310-334.

Haney Lopez, Ian. White By Law: The Legal Construction of Race. New York: New York University Press, 1996. 
Hegwood, Robert. "Erasing the Space Between Japanese and American: Progressivism, Nationalism, and Japanese American Resettlement in Portland, Oregon, 1945-1948," Master's Thesis, January 1, 2011. https://dr.archives.pdx.edu/xmlui/handle/psu/7070.

Hirobe, Izumi. Japanese Pride, American Prejudice: Modifying the Exclusion Clause of the 1924 Immigration Act. California: Stanford University Press, 2001.

Horowitz, David A. "The Klansman as Outsider: Ethnocultural Solidarity and Antielitism in the Oregon Ku Klux Klan of the 1920s." The Pacific Northwest Quarterly, 80 (1989), 12-20.

Ichioka, Yuji. "Attorney for the Defense: Yamato Ichihashi and Japanese Immigration." Pacific Historical Review 55 (1986): 192-225.

Ichioka, Yuji, Gordon H. Chang, and Eiichiro Azuma. Before Internment: Essays in Prewar Japanese American History. Stanford, Calif: Stanford University Press, 2006.

Ichioka, Yuji. "The Early Japanese Immigrant Quest for Citizenship: The Background of the 1922 Ozawa Case." Amerasia 4 (1977): 1-22.

Ichioka, Yuji. "Japanese Associations and the Japanese Government: A Special Relationship, 1909-1926.” Pacific Historical Review 46 (1977): 409-437.

Ichioka, Yuji. The Issei: The World of the First Generation Japanese Immigrants, 1885-1924. New York: The Free Press, 1988.

Iriye, Akira. Across the Pacific: An Inner History of American-East Asian Relations. Chicago: Imprint Publications, 1967.

Jacobson, Matthew Frye. Whiteness of a DIfferent Color: European Immigrants and the Alchemy of Race. Cambridge: Harvard University Press, 1998.

Johnson, Daniel P. "Anti-Japanese Legislation in Oregon, 1917-1923." Oregon Historical Quarterly 97 (1996): 176-210.

Katagiri, George. "Japanese Americans in Oregon." The Oregon Encyclopedia, http://www.oregonencyclopedia.org/articles/japanese_americans in_orego $\mathrm{n}$ immigrants from the west/\#.VjYwQ66rTeQ Accessed October 30, 2015.

Kennedy, Edward M. "The Immigration Act of 1965." The Annals of the American Academy of Political and Social Science, 367 (September 1966): 137-149.

LaFeber, Walter. The Clash: U.S.-Japanese Relations Throughout History. New York: Norton, 1997.

Lake, Marilyn and Henry Reynolds. Drawing the Global Colour Line: White Men's Countries and the International Challenge of Racial Equality. Cambridge, UK: Cambridge University Press, 2008.

Lew-Williams, Beth. "Before Restriction Became Exclusion: America's Experiment in Diplomatic Immigration Control." Pacific Historical Review 83 (2014): 24-56.

Lynch, Robert Newton. "The Development of the Anti-Japanese Movement." Annals of the American Academy of Political and Social Science 93 
(1921): 47-50.

McClain, Charles, ed. Asian Americans and the Law: Historical and Contemporary Perspectives. New York: Garland Publishing, 1994.

McKenzie, Roderick Duncan. Oriental Exclusion: The Effect of American Immigration Laws, Regulations, and Judicial Decisions Upon the Chinese and Japanese on the American Pacific Coast. New York: American Group, Institute of Pacific Relations, 1927.

Nagae, Peggy. "Asian Women: Immigration and Citizenship in Oregon." Oregon Historical Quarterly 113 (2012): 334-359.

Nomura, Gail M. "Significant Lives: Asia and Asian Americans in the History of the U.S. West." The Western Historical Quarterly 25 (1994): 69-88.

Park, John S.W. Elusive Citizenship: Immigration, Asian Americans, and the Paradox of Civil Rights. New York: New York University Press, 2004.

Robinson, Greg. After Camp: Portraits in Midcentury Japanese American Life and Politics. Berkeley: University of California Press, 2012.

Robinson, Greg. "Paul Robeson and Japanese Americans." Nichi Bei Times (San Francisco), March 13, 2008. Shanks, Cheryl. Immigration and the Politics of American Sovereignty, 1890-1990. Ann Arbor: University of Michigan Press, 2001.

Scott, Leslie M. “'The Oregonian' in Oregon History,” Oregon Historical Quarterly 29 (September 1928), 225-235.

Slayer, Lucy E. "Baptism By Fire: Race, Military Service, and U.S. Citizenship Policy, 1918-1935." The Journal of American History 91 (2004): 847876.

Stalker, Nancy. "Suicide, boycotts, and embracing Tagore: The Japanese popular response to the 1924 U.S. Immigration Exclusion Law." Japanese Studies 26 (2006): 153-170.

Stein, Harry H. "The Oregonian Navigates the Great Depression." Oregon Historical Quarterly 114 (2013): 174-203.

Stone, Jason. "Portland Morning Oregonian." Historic Oregon Newspapers website, University of Oregon Libraries, http://oregonnews.uoregon.edu/history/oregonian/. Accessed Oct. 30, 2015.

Takaki, Ronald. A Different Mirror: A History of Multicultural America. Boston: Back Bay Books, 1993.

Takaki, Ronald. Strangers From A Different Shore: A History of Asian Americans. New York: Little, Brown and Company, 1989.

Taylor, Sandra C. "The Ineffectual Voice: Japan Missionaries and American Foreign Policy, 1870-1941." Pacific Historical Review 53 (1984): 20-38.

Toll, William. "Permanent Settlement: Japanese Families in Portland in 1920." The Western Historical Quarterly 28 (1997):18-43.

Toy, Eckard. "The Ku Klux Klan in Tillamook, Oregon." The Pacific Northwest Quarterly, 53(April 1962): 60-64.

Toy, Eckard. "Whose Frontier? The Survey of Race Relations on the Pacific 
Coast in the 1920s." Oregon Historical Quarterly 107 (2006): 36-63.

Volpp, Leti. “"Obnoxious To Their Very Nature': Asian Americans and Constitutional Citizenship." Citizenship Studies 5 (2001).

Wilson, Robert A. and Bill Hosokawa. East To America: A History of the Japanese in the United States. New York: William Morrow and Company, 1980.

Yasui, Barbara. "The Nikkei in Oregon, 1834-1940." Oregon Historical Quarterly 76 (1975): 225-257. 


\section{Newspaper articles}

"Japanese Not White Persons," Oregonian, June 28, 1894, 4.

"Our Japanese Citizens," Oregonian, February 6, 1898, 6.

"Citizenship of Chinese," Oregonian, April 21, 1900, 3.

"Danger to the Nation: Naturalization Laws Not Stringent Enough," Oregonian, September 29, 1901, 12.

“May Japanese Practice Law?" Oregonian, May 17, 1902, 4.

"No Open Door: Immigration and Naturalization Laws Too Lax for Good," Oregonian, January 22, 1904

"Ito Guest of Honor: Banquet Given for Japanese Director-General," Oregonian, June 11, 1905, 15.

"Suspend Fight in Court: Lawyers for Japanese Await Result of Metcalf's Inquiry," Oregonian, November 3, 1906, 1.

"California Is In Rebellious Mood: Resents Roosevelt's Words on Japan," Oregonian, December 6, 1906, 1.

"Cushman Favors Japanese: Believes Color Does Not Make Good Americans," Oregonian, December 6, 1906, 4.

"Depends on Treaty's Terms: Jenkins Says If They Don't Cover Schools, Japan Can't Complain," Oregonian, December 6, 1906, 4.

"Immigration Real Question: Wheeler Says That It Must Be Settled In Cooperation With Japan," Oregonian, December 6, 1906, 4.

"Wants No Japanese Citizens: Mead Declares Opposition to Naturalization Bill," Oregonian, December 6, 1906, 4.

"Will Never Mix With Japanese: Kahn Voices California's Opposition to the Brown Orientals - Fears Not War With Japan," Oregonian, December 12, 1906, 2.

"Asiatic Races Excluded: California Legislators Would Deny All Citizenship Rights," Oregonian, January 25, 1907, 1.

"Exclude Yellow Races: California Senate Opposes Granting Citizenship to Japanese," Oregonian, March 10, 1907, 8.

"May Make Japs Citizens," Oregonian, May 16, 1907, 5.

"Waiting to Cross Borderline: 4000 Japanese in Mexico Waiting to Come Into United States," Oregonian, July 1, 1907, 9.

"Facts on Japanese Question: Great Britain Not Likely to be Drawn into a war," New York Times, July 3, 1907, 1.

"Flocking Over Border: Japanese Violate Immigration Law by Coming Through Mexico," Oregonian, July 5, 1907, 4.

"Make Japanese Citizens," New York Times, July 14, 1907, 6.

"Aoki Urges Intermarriage: Japanese Ambassador Declares It Is Solution of Race Difference," Oregonian, July 14, 1907, 1.

"Japanese Ready to Fight America: Hordes of Brown Men in Mexico," Oregonian, July 14, 1907, 1.

"Japanese Ready To Fight America: Hordes of Brown Men in Mexico," 
Oregonian, July 14, 1907, 1.

"Army Dwindles to 400: Mexican Colonel Punctures Story of Japanese Invasion," Oregonian, July 17, 1907, 2.

"Japanese Flock Across Border: Thousands Landing in Mexico Then Stealing

Into United States: Getting Ready for War,” Oregonian, July 27, 1907, 14.

"Aliens and Citizens: Questions About United States Naturalization Laws

Answered," Oregonian, August 14, 1907, 8.

"New Law Relating to Naturalization," Oregonian, August 25, 1907, 43.

“Japan Doubtless Will Understand," Oregonian, September 12, 1907, 8.

"Japanese Evade the Law: Get Passports To Go To Mexico But Stay in the United States," Oregonian, September 15, 1907, 4.

"Uncle Sam Has Cause to Worry: Japanese Pouring In Over Border In Such Vast

Numbers As To Create Alarm," Oregonian, October 7, 1907, 4.

"Want American Brides Japanese Arranging For Emigration," Oregonian,

November 2, 1907, 18.

"The Japanese Puzzle," Oregonian, November 16, 1907, 8.

"Misunderstood Race Problem," Oregonian, November 29, 1907, 10.

"Work for Law to Exclude Japanese. Trade Unionists Form Local Branch of

Asiatic Exclusion League," Oregonian, December 7, 1907, 10.

"Supreme Court Justice Sounds Warning: World May Have to War on Japanese

and Chinese," Oregon Journal, January 11, 1908.

"Needlessly Sensitive," Oregonian, January 13, 1908, 6.

"Cheap Charlie in Seattle," Oregon Journal, May 19, 1908.

"Japanese in Portland," Oregon Journal, May 23, 1908.

"The Japanese Point Of View," Oregon Journal, June 1, 1908.

"Shut Out Asiatics: California Democrats want total exclusion," Oregonian,

September 5, 1908, 5.

“Keeping Out the Japanese," Oregonian, October, 16, 1908, 10.

"Book review of Powers of the American People by Masuji Miyakawa,"

Oregonian, November 8, 1908, 11.

"Barring the Undesirables," Oregonian, December 11, 1908, 10.

"American Becomes Jap: Miss Estella Finch First Foreigner to be Naturalized by

Mikado," Oregonian, January 13, 1909, 1.

“Anti-Japanese Bills," Oregonian, January 21, 1909, 8.

"Baiters of the Japanese," Oregonian, February 6, 1909, 8.

"Oregon Shies At Japanese Issue: Legislature Favors Leaving Settlement of

Matter Entirely to Congress," Oregonian, February 9, 1909, 6.

"Roosevelt Knows Strain is Tense. Single Misguided Act Might Force Rupture

with Nippon, in His Opinion," Oregonian, February 15, 1909, 4.

"The United States and Japan," Oregonian, February 16, 1909, 8.

"A Disgusting Spectacle," Oregonian, March 26, 1909, 10.

"Japanese Denied Citizenship: Court Holds Chief Steward in Navy Not Entitled

To Papers," Oregonian, May 5, 1909, 5.

"Pastors Would Refuse to Marry Japanese to White Persons. Stand Taken by 
Judges Also Indicates Such A Couple Would Find It Hard To Wed Here," Oregonian, August 15, 1909, 2.

"Miscegenation is Good. So Says Chicagoan, Who Would Better American

Race," Oregonian, August 19, 1909, 3.

"We Don't Mean It," Oregonian, November 5, 1909, 12.

"Is Japanese White Man? Fine Point Involved in Virginia Naturalization Case,"

Oregonian, November 27, 1909, 1.

"Jap Can't Be U.S. Citizen: Oriental, 'Tis Decided, Is Neither Black Nor White,"

Oregonian, February 2, 1910, 1.

"Japanese Labor Needed On Farms: California Commissioner Declares Help is

Essential to Development," Oregonian, May 30, 1910, 2.

"Bill to Prevent Mixed Marriages," Oregonian, February 3, 1911, 10.

"Intermarriage Not Taboo Bill is Killed in House at Salem, amid Protesting

Storm," Oregonian, February 19, 1911, 1.

"Naturalization Abuse Slap at Clean Politics," Oregonian, August 20, 1911, 4.

"Japanese Energy," Oregon Journal, May 1, 1912.

"Hindu Case Puzzles: Right to Citizenship Question of Difficulty," Oregonian,

May 28, 1912, 14.

“Japanese Editors to Meet Here," Oregonian, June 2, 1912, 19.

"Tragedies of Intermarriage," Oregonian, June 30, 1912, 6.

"Japanese Picnic Tonight," Oregonian, July 18, 1912, 11.

"Intermarriage and Race Prejudice," Oregonian, August 4, 1912, 6.

"Nippon Romance Reflects On Son: Citizenship Denied To Child of Japanese

Mother," Oregonian, August 16, 1912, 1.

"Assimilation of New Residents To Be Task of YMCA Workers," Oregonian, March 23, 1913, 10.

"Let California Try It," Oregonian, April 10, 1913, 8.

"Japan Reserves Right To Protest: Wilson and Chinda Discuss Alien Bill,"

Oregonian, April 13, 1913, 1.

"Sharp Clash Over Alien Bill Is Seen: Furore in Japan Causes Elimination of

Drastic Features in Senate," Oregonian, April 15, 1913, 4.

"Wilson Considers Japan's Protest: Effect on Alliances Is Being Studied,"

Oregonian, April 19, 1913, 1.

"Japanese Populace Bitter: Newspapers Outline Plan to Seize Hawaii and

Philippines," Oregonian, April 19, 1913, 4.

"The Jap and His Produce," Oregonian, April 19, 1913, 8.

"Portland Takes Issue: Chamber of Commerce Deprecates Action Affecting Japan

Trade," Oregonian, April 19, 1913, 12.

"The Root of the Trouble," Oregonian, April 20, 1913, 6.

"United States May Oppose California: Treaty Rights of Japanese at Issue,"

Oregonian, April 22, 1913, 1.

"This Is White Man's Country: Japs Are Too Arrogant and Must Be Tamed One

Day," Oregonian, April 30, 1913, 10.

"Bryan Optimistic in Latest Report: Assistant Holds That New Bill Complies 
With Treaty," Portland Telegram, May 1, 1913.

"Japanese Ready to Ask Naturalization: Nipponese Plan To thus Solve Present

Trouble and Be Assimilated," Portland Telegram, May 1, 1913.

"Checking the Yellow Peril," Oregonian, May 3, 1913, 10.

"Treaty Is Quoted: Japan Resents Being Placed In Inferior Position," Oregonian, May 7, 1913, 7.

"Naturalization is Asked: Joseph Man From Japan Desires to Become an American," Oregonian, May 9, 1913, 2.

"Japan Situation Becomes Tense: Tokio's Attitude Remains in Doubt," Oregonian, May 19, 1913, 1.

"Tokio Still Shows Faith: Likelihood of Estrangement of Peoples, However, Admitted," Oregonian, May 19, 1913, 2.

Untitled editorial, Oregonian, May 20, 1913, 8.

"Japanese Women Form First Club: Fair Nipponese of Seattle Become 'Americanized,"' Oregonian, May 21, 1913, 1.

"Note Calms Japan, Washington Hears: Friendly Spirit of America's Reply

Strikes a Responsive Chord at Tokio," New York Times, May 22, 1913, 2.

"Japan's Emperor Is Suddenly Ill: Attention Is Diverted From Alien Bill," Oregonian, May 23, 1913, 1.

"Japan Not in Racial Sympathy: California Issue Will Not Be Settled by Technical Definition," Oregonian, May 23, 1913, 10.

"Sisson Puts State Above All Treaties: No Nation Can Dictate Land Laws To Us, He Tells the National House," New York Times, May 24, 1913, 2.

"Japanese Problems Put Before Guthrie: New Ambassador is Told That Situation Requires Sympathetic Treatment," New York Times, May 24, 1913, 1.

"Japan To Make More Demands: Administration Fears She Will Ask For Full Citizenship," The Morning Leader, May 25, 1913.

"Japan's Answer To Be Ready Soon: Resort to Naturalization Laws for Relief Now Believed Improbable," Oregonian, June 1, 1913, 6.

"Status of Japan's Contention: Legal Aspects of Alien Land-Owner Controversy Delved Into," Oregonian, June 25, 1913, 8.

"Japanese Concerned Over Race Outlook: Tokio Editor Advises People to Seek

Naturalization in Other Countries," Oregonian, July 20, 1913, 5.

"Japanese Cause Aided: California Nipponese Hires Trained Press Agent,"

Oregonian, August 8, 1913, 4.

"Book review of Asia at the Door by K.K. Kawakami," Oregonian, April 12, 1914, 11.

"Alien Land Issue Near Hague Stage: Offer of New Treaty is Refused by Tokio," Oregonian, June 26, 1914, 1.

"America's Export Opportunity: Japanese Author Sees Great Trade Possibilities in Orient," Oregonian, November 13, 1914, 10.

“America Urged To Go Into Orient For Trade," Oregonian, February 14, 1915, 10.

"Hearst Story Is Denounced: Japanese Throws New Light On Supposed War 
Forecast," Oregonian, October 17, 1915, 9.

"Citizenship Plan New: Admission Of All On Reasonable Basis Is Advised," Oregonian, November 23, 1915, 15.

“A New Immigration Policy,” Oregonian, November 26, 1915, 8.

"Japanese Is Critic: Preparedness Attitude of This Country Declared Faulty,"

Oregonian, May 2, 1916, 13.

"Japan Is Declared Friendly: B. Takita Says Reported Aid to Carranza is

Ridiculously Absurd," Oregonian, June 24, 1916, 8.

"Noted Japanese Here: Kayan Kayahara, Journalist, Asserts Friendship of

Nations," Oregonian, November 22, 1916, 13.

"Japanese Citizen Applies: White Woman, Divorced From Oriental, May Get

Papers," Oregonian, February 22, 1917, 1.

"Jap Demands Citizenship: Appeal Is First To Reach Federal Supreme Court in

California," Oregonian, May 25, 1917, 3.

"600 Citizens Gained: Judge Wolverton To Admit Class of Spruce Workers,"

Oregonian, August 8, 1918, 7 .

"Japanese To Be Citizens: Soldiers of United States Army Await Privilege of

Naturalization," Oregonian, December 17, 1918, 1.

"Japanese Made Citizen," Oregonian, January 19, 1919, 1.

"Indelicate," Oregonian, January 28, 1919, 8.

"An Immigration Policy," Oregonian, February 27, 1919, 10.

"Make The Law Same For All," Oregonian, March 22, 1919, 8.

"Citizenship is Denied: Judge Smith Holds Service in U.S. Army Does Not

Exempt Japanese," Oregonian, April 10, 1919, 1.

"Cities on Coast Must Make Trade For the Orient: Portland Expected to Take

Lead in Lumber Shipments, but Will Need to Take Return Cargoes,"

Oregon Journal, April 13, 1919.

"Equality Appeal of Japan is Defeated: Vote is Eleven For to 6 Against in League of Nations Commission, but Because Not Unanimous Amendment Is

Rejected," Oregon Journal, April 13, 1919.

“Japanese Denied Citizenship By Federal Court,” Oregon Journal, April 13, 1919.

"Court To Decide Asiatics' Rights: Jurist To Decide If War Service Is Citizenship Key," Oregonian, May 14, 1919, 13.

"Immigration Bill Is Held Pro-Japanese: Gulick Measure Denounced by Senator

Phelan," Oregonian, August 18, 1919, 2.

"Session Expect To Finish Today: Day Is Unlucky for Aliens, Especially

Japanese," Oregonian, January 17, 1920, 1.

"That Anti-Japanese Resolution," Oregonian, January 23, 1920, 10.

"Bill Aims At Japanese," Oregonian, February 2, 1920, 15.

"The Japanese 'Invasion,"” Oregon Journal, February 29, 1920.

"Three Japanese Are Admitted To Full Citizenship," Oregon Journal, March 3, 1920.

“Jap Assimilation In America Argued: 'We're Ready for Melting Pot,' Say 
Nipponese" Oregonian, July 17, 1920, 6.

"Probers Plead For More Time: Committee Wants Diplomatic Solution of Japanese Problem," Oregonian, July 21, 1920, 3.

"Judge Denies Japanese Vote: Soldier of Hawaiian Infantry Loses Court Fight in California," Oregonian, July 21, 1920, 3.

"Citizenship Bar On Japanese Is Urged: Rigid Exclusion Advised At Tacoma Hearing," Oregonian, August 3, 1920, 4.

"Japanese Deny Aiding Aliens To Enter U.S.: Officers of Oregon Association Issue Statement In Reply to Charges Made Before Committee," Portland Telegram, August 5, 1920.

"Committee to Ask Fair Law For Japanese," Portland Telegram, August 7, 1920.

"Japan More Bitter: Feeling Increased By Statement of Johnson," Oregonian, August 7, 1920, 6.

"Japanese Prober Studies State," Oregonian, August 7, 1920, 6.

"Sentiment On Japanese In State Varies: Majority Oppose Brown Man as Menace, but Many Would Tolerate Him in Limited Number, Report to Governor Declares," Oregon Journal, August 20, 1920.

"The Real Japanese Problem," Portland Telegram, September 2, 1920.

"California Starts Anti-Japanese War," Oregonian, September 3, 1920, 7.

"Japanese Take Action: American-Born Orientals Memorialize Congressional Body," Oregonian, September 27, 1920, 2.

"Japan-U.S. Secret Diplomacy Target: 100,000 Orientals in America No Menace, Says Okuma," Oregonian, September 27, 1920, 5.

"Gary Avers Japan Is Not Seeking War: If Clash Comes, U.S. Is Held Most To Blame," Oregonian, December 16, 1920, 6.

"Sato Seeks Citizenship: Japanese Veteran of U.S. Army Wants Honor," Oregonian, December 16, 1920, 6.

"Citizenship in U.S. Is Granted to 48: Admission Refused to One Japanese ExSoldier," Oregonian, December 17, 1920, 14.

"Oregon and the Japanese Problem," Portland Telegram, January 7, 1921.

"Oregon Is For Americans Only, Declares Olcott: Urges Legislative Members to Enact Laws Which WIll Let the World Know Where We Stand on the Japanese Question," Portland Telegram, January 11, 1921.

"Says Alien Legislation as Contemplated Is All Wrong," Portland Telegram, January 11, 1921.

“Opposition Develops To Proposed Curb on Orientals in Oregon," Portland Telegram, January 11, 1921.

"Veterans Ask Joint Action on Alien Law: Washington-Oregon Committee to Draw Drastic Anti-Oriental Legislation Will Be Requested," Portland Telegram, January 11, 1921.

“Oregon Faces Japan,” Portland Telegram, January 12, 1921.

“The Governor's Message,", Oregonian, January 12, 1921, 12.

"Strict Economy Everywhere is Urged by the Governor," Oregonian, January 12, 1921, 8. 
“The Japanese Among Us," Portland Telegram, April 11, 1921.

"Naturalization of Japanese," Oregonian, June 9, 1921, 8.

"Legion Will Open Convention Today: Oregon Delegation Arrives in Kansas

City," Oregonian, October 31, 1921, 2.

"Hope Put In Arms Limit: Portland Japanese Want Session To Succeed,"

Oregonian, November 12, 1921, 8 .

“Our Japanese Farmers," Portland Telegram, November 17, 1921.

"Alien Ownership of Land," Oregonian, January 25, 1922, 8.

"Citizenship and Naturalization," Oregonian, March 25, 1922, 12.

"Japan's Own Medicine," Oregonian, June 23, 1922, 8.

"Their Protest," Oregon Journal, August 23, 1922.

"Japanese Save Subsidy: Orientals Naturalized in State of Brazil," Oregonian, September 28, 1922, 6.

"Right Of Japanese Citizenship Up: Case Before Supreme Court For Decision," Oregonian, October 4, 1922, 2.

"Education and the State," Oregonian, November 6, 1922, 10.

"Multnomah Vote is Won by Pierce," Oregonian, November 9, 1922, 1.

"The Big Wind," Oregonian, November 9, 1922, 12.

"Japanese Lose Citizenship Suit," Oregonian, November 14, 1922, 1.

"Japanese Naturalization," New York Times, November 15, 1922, 1.

“Tokio Press Still Angry,” New York Times, November 18, 1922, 1.

"Japanese Soon Will Own Rich Tracts in California: Forty Thousand Americanborn Orientals Declared Sure to Come Into 800,000 Acres of Fine Agricultural Land," Oregonian, November 19, 1922, 8.

"Alien Ruling in Doubt: Japanese May Lose Citizenship Papers Granted By Judge," Oregonian, December 8, 1922, 10.

"Bill Would Bar Aliens: Amendment to Constitution Is Planned To Restrict Japanese," Oregonian, December 23, 1922, 15.

Untitled Letter to the Editor, Oregonian, March 26, 1923, 8.

"Armenian Status Asked: Immigrant Test Case to Designate Race," Oregonian, November 25, 1923, 4.

“Japan's Complaint Baseless," Oregonian, April 15, 1924, 12.

“Japanese Desire For Influx Denied," Oregonian, April 15, 1924, 2.

"The Only Possible Reply," Oregonian, April 16, 1924, 12.

"No Real Cause of Offense," Oregonian, April 21, 1924, 8.

"Immigration and Exclusion," Oregonian, May 27, 1924, 8.

"Strong Protest Framed by Japan," Oregonian, May 28, 1924, 1.

"Japanese Kills Himself Near Tokio Embassy; Hara-kiri Victim Assails Us, Asks

Vengeance," New York Times, June 1, 1924, 1.

“Japan's Ground of Protest," Oregonian, June 3, 1924, 12.

“America Answer's Japanese Protest," Oregonian, June 17, 1924, 1.

"Nippon Officials Offend Americans" Oregonian, June 25, 1924, 2.

"Old Glory Is Cut Down," Oregonian, July 1, 1924, 1.

“Japanese Kindly To U.S. Students," Oregonian, July 20, 1924, 2. 
"Friendly Mission Cordially Received," Oregonian, July 23, 1924, 21.

"Japanese Shower Honors On U.S. Visitors," Oregonian, August 9, 1924, 11.

"Japanese Life Is Changing, But Holds Old Traditions," Oregonian, August 19, 1924, 25.

“Japanese Said To Revere Great American Patriots," Oregonian, August 21, 1924, 16.

"Out of Step," Oregonian, January 7, 1945, 18.

"Hysteria in Oregon," Lewiston Morning Tribune, March 18, 1945, 1.

“12,000 Nisei Return West," Oregonian, August 29, 1945, 6.

"Japanese Coast Return 'Better Than Expected," Oregonian, February 10, 1946, 14.

"Nisei Lauded For War Role: Gold Star Mothers Banquet Guests," Oregonian, August 12, 1946, 7.

"Alien Land Laws Face Court Test," Oregonian, April 6, 1947, 1.

"Judge Declares Japanese May Live on Leased Land," Oregonian, October 12, 1947, 18.

"Repeal of Western Laws on Rights of Aliens Asked," Oregonian, October 30 $1947,8$.

"Senate Approves Bill on Japanese," Oregonian, April 1, 1948, 8.

Dusenbery, Verne. "Japanese Bill," Oregonian, April 25, 1948, 30.

"Asiatics Ban Repeal Asked," Oregonian, February 9, 1949, 4.

"State Court Voids Alien Land Law," Oregonian, March 30, 1949, 1.

"Return to First Principles," Oregonian, April 12, 1949, 16.

"House Votes Aid to Asians," Oregonian, June 7, 1949, 6.

"Naturalizing Act Awaiting Action," Oregonian, July 27, 1950, 6.

"Naturalization Bars Lifted for Asiatics," Oregonian, August 15, 1950, 6.

"Walter Judd: Mr. Justice," Nichi Bei Times, December 24, 1950.

"House Okeys Bill to Aid Orientals," Oregonian, , February 20, 1951, 4.

"Plan Favors Entry Quota," Oregonian, January 29, 1952, 4.

"Lehman Criticizes Immigration Bill," New York Times, April 6, 1952, 60.

"House Vote Would Lift Alien Bar," Oregonian, April 26, 1952, 1.

"The Anti-Immigration Bill," New York Times, May 14, 1952, 26.

"Immigration Bill Approved," Oregonian, June 12, 1952, 6.

"Demos Worried Over Quota Bill," Eugene Register-Guard, 6/17/52.

"President Vetoes Immigration Bill as Discriminatory," New York Times, June 26, $1952,1$.

"Text of Truman's veto speech", New York Times, June 26, 1952, 14.

"House Overrides Veto By Truman," Oregonian, June 27, 1952, 1.

"Senate Roll-Call," New York Times, June 28, 1952, 10.

"Victory for a Bad Bill," New York Times, June 28, 1952, 18.

"Immigration Law Assailed On Coast," New York Times, October 15, 1952, 45.

"Citizenship Lure Slight," Oregonian, December 26, 1952, 11.

"Actress Hedy Lamar Gets US Citizenship," Oregonian, April 11, 1953, 11.

“42 Japanese Prepare for Citizenship,” Oregonian, April 27, 1953, 14. 
"Japanese Take First Step Along Citizenship Route" Oregonian, May 29, 1953, 5.

"Youngest CItizen Sworn In at Court Ceremony, Along with Natives of 22

Foreign Countries ," Oregonian, September 10, 1953, 12.

"120 Citizens Greeted in Naturalization Program: Judge East Urges Exercise of Right to Cast Ballot," Oregonian, September 6, 1956, 38. 